\title{
Review
}

\section{Organic carbon dynamics in mangrove ecosystems: A review}

\author{
Erik Kristensen $^{\mathrm{a}, 1, *}$, Steven Bouillon ${ }^{\text {b,c,1 }}$, Thorsten Dittmar ${ }^{\mathrm{d}, 1}$, Cyril Marchand ${ }^{\mathrm{e}, 1}$ \\ ${ }^{a}$ Institute of Biology, University of Southern Denmark, DK-5230, Odense M, Denmark \\ ${ }^{\mathrm{b}}$ Vrije Universiteit Brussel, Department of Analytical and Environmental Chemistry, Pleinlaan 2, B-1050 Brussels, Belgium \\ ${ }^{\mathrm{c}}$ Netherlands Institute of Ecology, Centre for Estuarine and Marine Ecology (NIOO-KNAW), Yerseke, The Netherlands \\ ${ }^{\mathrm{d}}$ Department of Oceanography, Florida State University, Tallahassee, FL 32306-4320, USA \\ ${ }^{\mathrm{e}}$ Institut de Recherche pour le Développement (IRD), UR 103 CAMELIA, Nouméa BP A5, 98848, New Caledonia
}

Received 4 April 2007; received in revised form 24 July 2007; accepted 4 December 2007

Available online 8 December 2007

\begin{abstract}
Our current knowledge on production, composition, transport, pathways and transformations of organic carbon in tropical mangrove environments is reviewed and discussed. Organic carbon entering mangrove foodwebs is either produced autochthonously or imported by tides and/or rivers. Mangrove litter and benthic microalgae are usually the most important autochthonous carbon sources. Depending on local conditions, phytoplankton and seagrass detritus imported with tides may represent a significant supplementary carbon input. Litter handling by the fauna not only affects microbial carbon transformations, but also the amount of organic carbon available for export. Most mangrove detritus that enters the sediment is degraded by microorganisms. Aerobic respiration and anaerobic sulfate reduction are usually considered the most important microbial respiration processes, but recent evidence suggests that iron respiration may be important in mangrove sediments as well. Organic carbon that escapes microbial degradation is stored in sediments and in some mangrove ecosystems, organic-rich sediments may extend to several meters depth. Many mangrove forests also lose a significant fraction of their net primary production to coastal waters. Large differences occur between mangrove forests with respect to litter production and export. Mangrove-derived DOC is also released into the water column and can add to the total organic carbon export. Numerous compounds have been characterized from mangrove tissues, including carbohydrates, amino acids, ligninderived phenols, tannins, fatty acids, triterpenoids and $n$-alkanes. Many of these may, together with stable isotopes, exhibit a strong source signature and are potentially useful tracers of mangrove-derived organic matter. Our knowledge on mangrove carbon dynamics has improved considerably in recent years, but there are still significant gaps and shortcomings. These are emphasized and relevant research directions are suggested.
\end{abstract}

(C) 2007 Elsevier B.V. All rights reserved.

Keywords: Mangrove forest; Carbon dynamics; Import; Export; Biogeochemistry; Burial

\section{Contents}

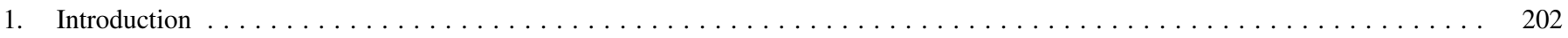

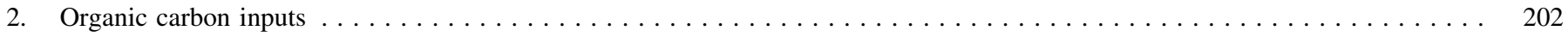

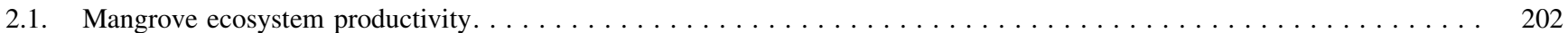

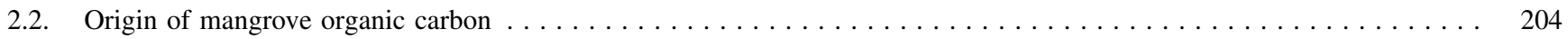

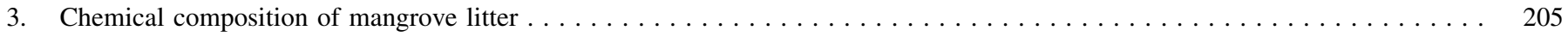

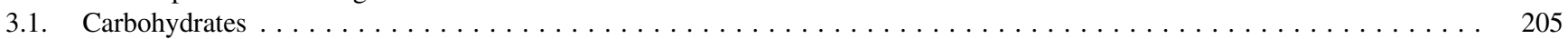

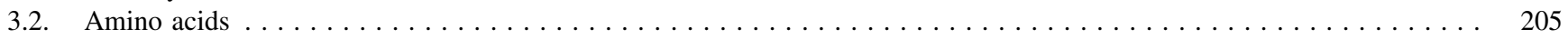

3.3. Tannins . . . . .

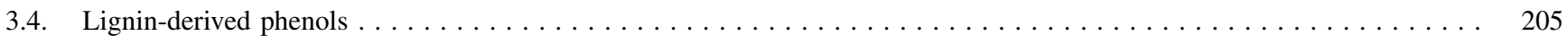

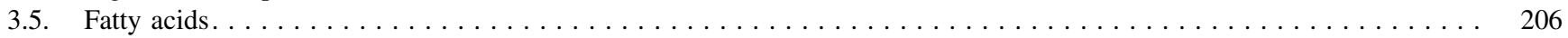

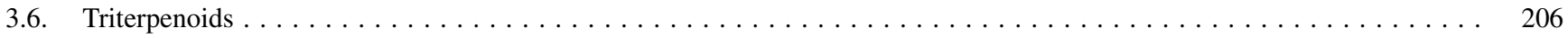

\footnotetext{
* Corresponding author. Tel.: +45 6550 2754; fax: +45 65930457.

E-mail address: ebk@biology.sdu.dk (E. Kristensen).

${ }^{1}$ All authors have contributed equally to this publication.
} 


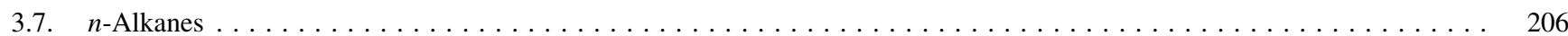

4. Mangrove foodwebs and the role of fauna in organic carbon processing. . . . . . . . . . . . . . . . . . . . 206

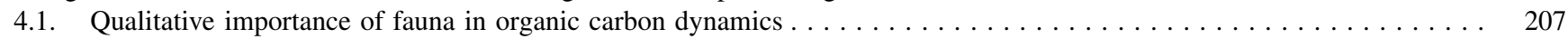

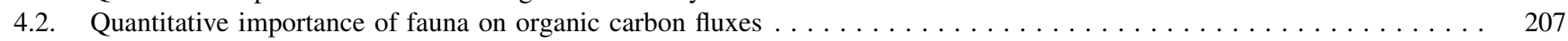

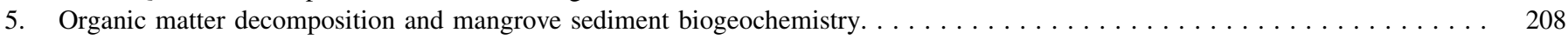

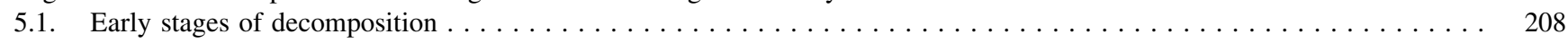

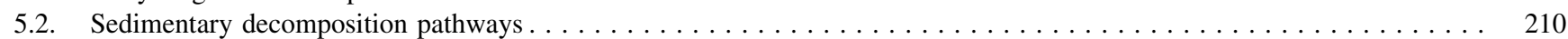

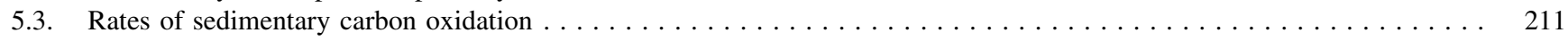

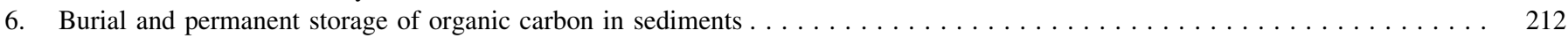

7. Outwelling and dispersal of mangrove organic matter $\ldots \ldots \ldots \ldots \ldots$

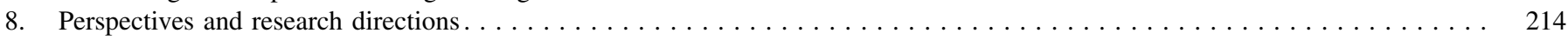

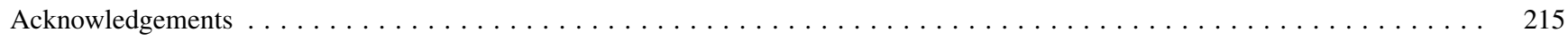

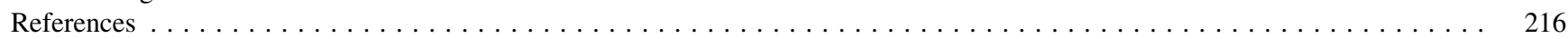

\section{Introduction}

Mangrove forests are known to be highly productive ecosystems with the capacity to efficiently trap suspended material from the water column. Litter from trees (leaves, propagules and twigs) and subsurface root growth provide significant inputs of organic carbon to mangrove sediments (Alongi, 1998). Litterfall is likely to represent about one third of the net primary production (Alongi et al., 2005a). A range of other sources may also provide important organic carbon inputs; including allochthonous riverine or marine material (e.g., seagrasses), autochthonous production by benthic or epiphytic micro- or macroalgae, and local water column production by phytoplankton (Bouillon et al., 2004). As a consequence, mangrove environments are sites of intense carbon processing with a potentially high impact to the global carbon budget (Borges et al., 2003; Dittmar et al., 2006; Alongi, 2007).

Mangrove-derived detritus is an important food source for decomposer food webs including many macroinvertebrates, such as sesarmid crabs (Grapsidae) that are notable in their ability to consume mangrove litter (Fratini et al., 2000; Cannicci et al., 2008). The more moderate, but in many cases considerable input of local or imported algal detritus is consumed by other animal species such as fiddler crabs (Ocypodidae) and various gastropods (Bouillon et al., 2002; Kristensen and Alongi, 2006). Irrespective of the pathways of organic matter consumption and food web structure, all organic matter that is not exported by tidal action enters the sediment where it is consumed, degraded and chemically modified. The degradation of organic matter in mangrove sediments is mediated by both aerobic and anaerobic microbial processes using a variety of electron acceptors. A fraction of mangrove detritus escapes degradation and is permanently buried within the mangrove sediments or adjacent ecosystems. While some mangrove forests largely retain detritus within their sediments (i.e. as degradation or burial), others lose a major fraction of their net primary production to adjacent coastal waters mainly through tidal forcing. Because of the regular tidal flooding and draining in many mangrove forests, the material exchange with adjacent waters can be very efficient.

In this contribution, we review and evaluate the current knowledge on organic carbon dynamics in mangrove ecosys- tems and its impact on other ecosystems. Fig. 1 provides an overview of the major pathways and pools of carbon associated with leaf litter and algal detritus in mangrove environments. We will first discuss the relative importance of various sources to the total ecosystem organic carbon balance and describe the chemical composition of mangrove tissues at the molecular level. Subsequently, we will discuss the function of food webs, including litter grazing invertebrates and microbial decomposers with emphasis on the behavior of organic carbon in mangrove sediments during early diagenesis, and the efficiency of permanent burial as a fate of mangrove production. Finally, we emphasize the role of outwelling and dispersal of mangrove derived organic matter that escapes decomposition for carbon dynamics in adjacent environments.

\section{Organic carbon inputs}

\subsection{Mangrove ecosystem productivity}

The most widely used proxy of mangrove productivity is annual litter fall, which is known to show a latitudinal gradient, being highest close to the equator (e.g., Twilley et al., 1992). Typical global average litterfall rates are in the order of $\sim 38 \mathrm{~mol} \mathrm{C} \mathrm{m}^{-2}$ year $^{-1}$ (Twilley et al., 1992; Jennerjahn and Ittekkot, 2002). It must be stressed, however, that this underestimates the total net $\mathrm{CO}_{2}$ fixation by mangroves, since it does not incorporate the wood and belowground biomass production (Middleton and McKee, 2001), nor DOC release through root exudates. Estimates indicate that belowground biomass makes up a substantial part $(10-55 \%)$ of the total mangrove biomass (Twilley et al., 1992; Matsui, 1998; Alongi and Dixon, 2000). A number of recent direct measurements of photosynthesis rates indeed suggest that net primary production (NPP) is significantly higher than litter fall estimates, the latter representing only $\sim 30 \%$ (range: $14-41 \%$ ) of the net canopy production (Alongi et al., 2005a). An alternative approach to estimate the net production is to include the (scarce) estimates of wood and root production. Twilley et al. (1992) estimated a global average wood production of $67 \mathrm{~mol} \mathrm{C} \mathrm{m}^{-2}$ year $^{-1}$, taking into account the latitudinal variation. A number of data on root production have recently become available, and from these, we calculate the (geometrical) mean ratio of root to leaf 


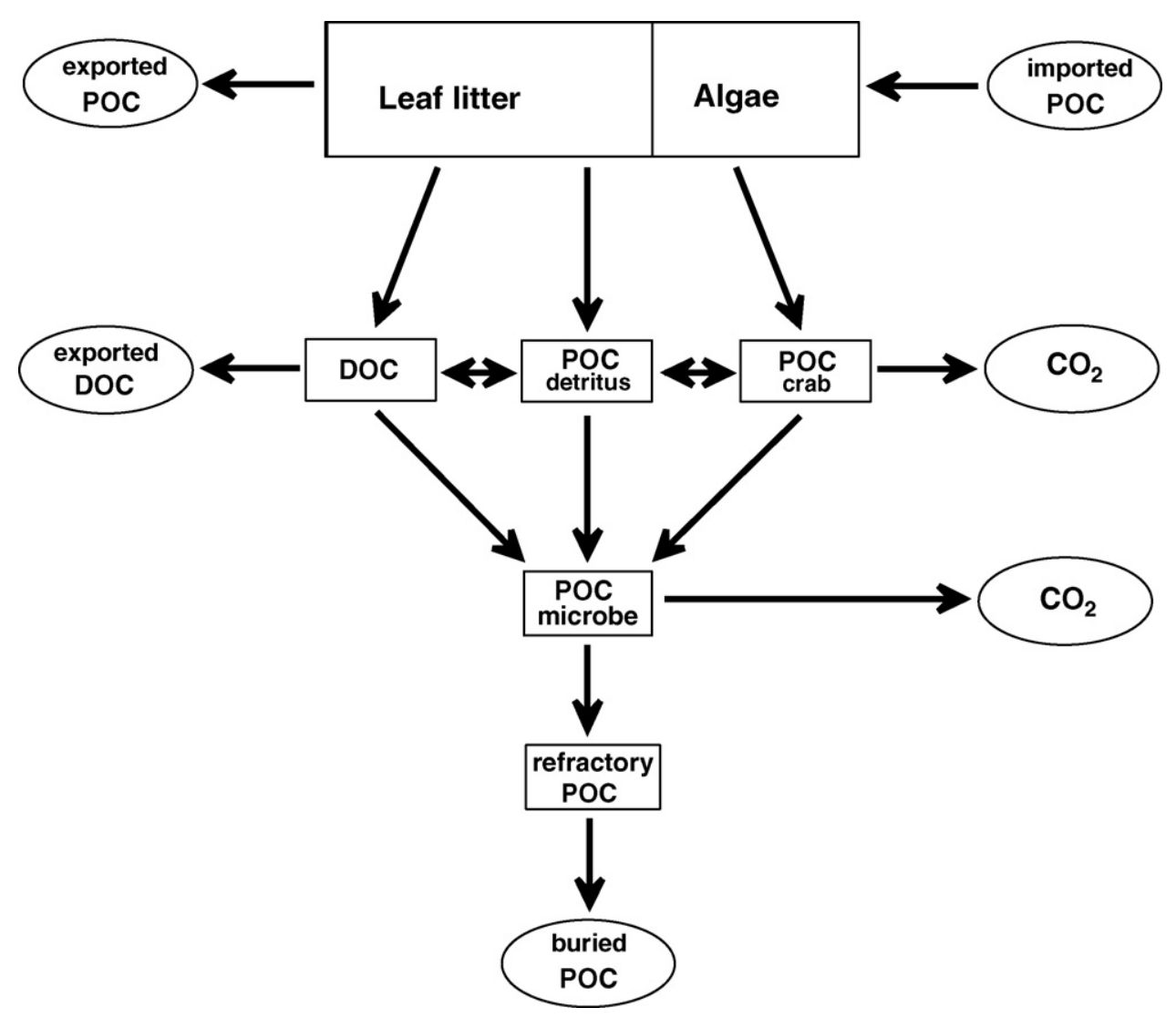

Fig. 1. Diagram showing the major pathways and pools of carbon associated with leaf litter and algal detritus in mangrove environments. Squares represent pools of organic carbon. Arrows represent transfer of carbon between pools through key processes like transport, leaching, microbial decay, and macrofaunal grazing. Ovals represent pools that are permanently displaced from biological transformation within the mangrove system (modified from Kristensen, 2008).

carbon production at $1.15 \pm 0.75(n=12$, data from McKee and Faulkner (2000) and Giraldo Sánchez (2005)), which allows us to estimate the global average mangrove root production at $44 \mathrm{~mol} \mathrm{C} \mathrm{m}^{-2}$ year $^{-1}$. Combining these data, the total NPP (leaf litter, wood and root production combined) can be estimated to be roughly $149 \mathrm{~mol} \mathrm{C} \mathrm{m}^{-2}$ year $^{-1}$. This suggests that litter fall comprises no more than $\sim 25 \%$ of the total NPP, consistent with the estimates presented in Alongi et al. (2005a). So far, budgeting and productivity studies in mangrove areas have primarily been based on litterfall estimates (e.g., Jennerjahn and Ittekkot, 2002), which obviously leads to underestimates of carbon dynamics.

The efficiency of mangrove systems in trapping suspended material from the water column likely depends on a range of factors such as the particle size, salinity, tidal pumping and the areal extent of the intertidal zone (e.g., Wolanski, 1995), but can be very high: 15-44\% (Victor et al., 2004), 30-60\% (Kitheka et al., 2002), and up to 80\% (Furukawa et al., 1997). The origin of the organic fraction in the water column is highly variable, and may include a mixture of marine or freshwater plankton, C3 or C4 terrestrial matter, mangrove litter and seagrass-derived material. The organic content of suspended matter is low, typically in the $2-4 \%$ range (Bouillon et al., 2003), which is comparable to or lower than that of mangrove sediments.
Rates of benthic primary production by microphytobenthos have been reported from different mangrove ecosystems, and range between 7 and $73 \mathrm{~mol} \mathrm{C} \mathrm{m}^{-2}$ year $^{-1}$ (Gattuso et al., 1998; Holmer et al., 2001; Kristensen and Alongi, 2006). The inputs from microalgae are generally considered to be low due to light limitation or inhibition by tannins (see Alongi, 1994). Productivity data for macroalgae are scarce, but some studies indicate that they may contribute significantly under certain conditions (e.g., $110-118$ mol C year ${ }^{-2} \mathrm{~d}^{-1}$ for lagoon systems see Koch and Madden (2001)). Phytoplankton densities and primary production have been found to be highly variable and it has been suggested that productivity may be significantly lower in estuarine mangrove areas (e.g. the Fly River delta, Papua New Guinea: $0.7-21 \mathrm{~mol} \mathrm{C} \mathrm{m}^{-2}$ year $^{-1}$, Robertson et al., 1992) than in mangrove-lined lagoons (e.g. Ivory Coast: up to $146 \mathrm{~mol} \mathrm{C} \mathrm{m}^{-2}$ year $^{-1}$, see references in Robertson and Blaber, 1992). The relative importance of phytoplankton to the total mangrove ecosystem primary productivity is expected to vary with geomorphology, water currents, turbidity and nutrient levels, e.g., 20\% for the Fly River delta, Papua New Guinea (Robertson et al., 1992), 50\% in Terminos Lagoon, Mexico (Day et al., 1987), and far exceeding mangrove inputs in other ecosystems (e.g. Wafar et al., 1997; Li and Lee, 1998). Despite a potentially high phytoplankton production in mangrove creeks, high turbidity 
and active microbial degradation within the water maintain many creeks as net heterotrophic systems, even during the day (Kristensen and Suraswadi, 2002).

\subsection{Origin of mangrove organic carbon}

Elemental composition and stable isotope signatures can provide clues on the origin of the sedimentary organic matter pool. Much of the variation in these proxies can be explained by a simple two-source mixing model whereby mangrove litter (characterized by high POC, high POC/PN ratios, and low $\delta{ }^{13} \mathrm{C}$ values) and suspended matter (low POC, low POC/PN ratios, variable but generally higher $\delta^{13} \mathrm{C}$ values) are taken as endmembers (Bouillon et al., 2003), similar to what has been found in salt marsh ecosystems (Middelburg et al., 1997). However, due to the limited number of studies which have simultaneously reported $\delta{ }^{13} \mathrm{C}$ values and $\mathrm{POC}$ and/or POC/PN data from mangrove sediments, the data presented in Bouillon et al. (2003) hold little information on the relative occurrence of the different situations encountered. A compilation of available data (Fig. 2A) shows that $58 \%$ of $\delta^{13} \mathrm{C}$ data are lower than $-25 \%$, and thus suggest an important input of mangrove litter $\left(\delta^{13} \mathrm{C} \sim-28\right.$ to $\left.-30 \%\right)$. On the other hand, the significant number of relatively high $\delta^{13} \mathrm{C}$ data $(-17$ to $-23 \%$ ) indicates large inputs of imported (phytoplankton, seagrasses in some ecosystems) and possibly local (microphytobenthos) ${ }^{13} \mathrm{C}$ enriched $\left(\delta^{13} \mathrm{C} \sim-16\right.$ to $-24 \%$ ) carbon sources. Accordingly, Wooller et al. (2003) suggested that dense microbial mats may provide a high input of organic carbon to certain mangrove sediments (up to 90\%), and similarly, Marchand et al. (2003, 2005 ) provided clear evidence that algal material can represent a significant fraction of the sedimentary organic carbon, in particular during the early stages of mangrove forest development.

Mangrove sediments are in general relatively rich in organic carbon with a median POC content of $2.2 \%$ (Fig. 2B). A fraction of $44 \%$ of the available data show POC less than $2 \%$ and $28 \%$ with values between 2 and $5 \%$. Since most mangrove forests occur along sedimentary coastlines in large estuaries and deltas, large quantities of suspended organic carbon brought in by tides or rivers are deposited along with local mangrove detritus (e.g. Victor et al., 2004 and references therein). The large majority (96\%) of mangrove sediments have POC/PN ratios above 10 (Fig. 2C), which is typical for subtidal marine sediments, and 47\% even exceed POC/PN ratios of 20. Although the large fraction of relatively high POC/PN ratios indicate that mangrove sediments contain a significant input of mangrove litter, the wide range is difficult to interpret. It may reflect either pure mangrove litter in an advanced stage of decomposition, or a variable contribution by other carbon sources. Apart from the indications outlined above, recent results based on the isotope composition of sediment organic carbon from mangrove systems where significant amounts of C4 vegetation occurs in the catchment areas, points out the potential importance of riverine-transported terrestrial material in mangrove systems (Bouillon et al., 2007a; Ralison and Bouillon, unpublished).
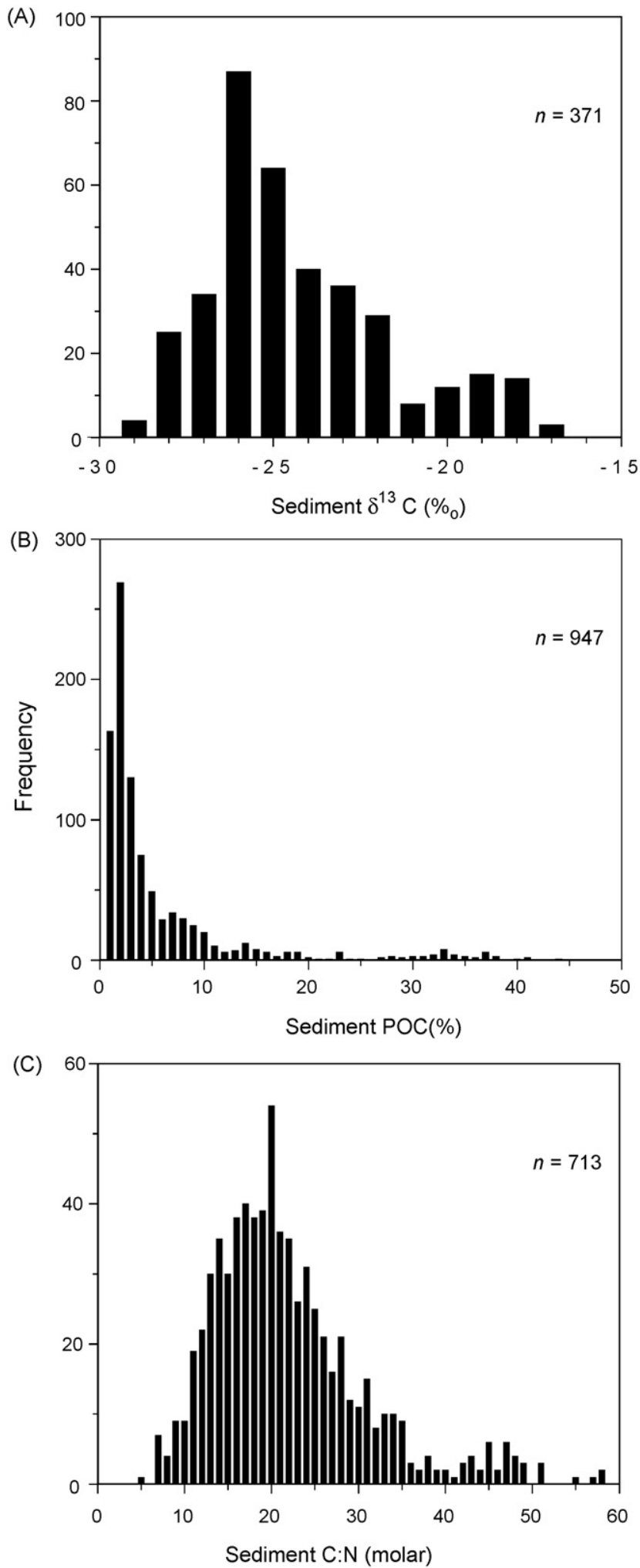

Fig. 2. Compilation of (A) bulk $\delta^{13} \mathrm{C}$, (B) bulk POC and (C) bulk POC:TN ratios of intertidal mangrove sediments. Only data where POC and POC:TN ratios were analyzed using standard elemental analyzer approaches are included. Compiled from various sources. The data and references are available upon request. 


\section{Chemical composition of mangrove litter}

Mangrove tissues (in particular Rhizophora leaves) have been characterized in various studies that focused on: (i) the nutritional quality of mangrove-derived organic matter, (ii) the specificity of certain biomarkers to trace mangroves in paleoenvironmental reconstructions, or (iii) the organic fluxes delivered to the oceans. Numerous compound classes have been identified, including carbohydrates, amino acids, lignin-derived phenols, tannins, fatty acids, triterpenoids and $n$-alkanes, and up to $50 \%$ of Rhizophora leaf biochemical composition can now be accounted for (Hernes et al., 2001). The general conclusion is that mangrove tissues exhibit a strong source signature and that some compounds are potentially useful tracers of mangrove-derived organic matter as they are preserved during diagenesis. These biochemical tracers can provide important complementary information for a successful interpretation of stable isotope data.

\subsection{Carbohydrates}

Carbohydrates represent the largest fraction of photosynthetically assimilated carbon in the biosphere. They are the most abundant constituents of vascular plants where they mostly occur in cell walls. Total carbohydrate yields can represent up to $65.5 \%$ of organic carbon in mangrove wood (Opsahl and Benner, 1999). Marchand et al. (2005) showed that the leaves of three different mangrove species (Avicennia germinans, Laguncularia racemosa, and Rhizophora mangle) are poorer than woody tissues in neutral sugars, with concentrations ranging from 12 to $32 \%$ and from 25 to $36 \%$ of the total organic carbon, respectively. Glucose is the most abundant neutral sugar in each of these species, representing $>50 \%$ of the total. About $80 \%$ of the glucose was found to be cellulosic, while other neutral sugars are mostly hemicellulosic. Moers et al. (1990) and Benner et al. (1990) demonstrated that $R$. mangle wood is mainly composed of glucose, xylose and arabinose, whereas the compositional pattern in $R$. mangle leaves is: glucose $>$ arabinose $>$ galactose $>$ rhamnose $>$ xylose. Leaves of $A$. germinans are richer in xylose compared with leaves from other mangrove species (Marchand et al., 2005; Opsahl and Benner, 1999). Even though mangrove tissues have typical carbohydrate signatures, these tend to disappear rapidly in the detritus pool since polysaccharides are highly reactive compounds relative to bulk organic carbon, and since microbial communities themselves synthesize new polysaccharides. Nevertheless, neutral carbohydrates show selective degradation patterns in mangrove sediments, which can provide specific details on their sources, despite their overall low concentrations. Marchand et al. (2005) showed that the debris deriving from mangrove roots strongly contributes to the organic enrichment of sediments, and can be discriminated using their content of xylose, and cellulosic monosaccharides. In contrast, algal mats developing on the sediment surface during the early stages of mangrove development are responsible for abundant rhamnose content.

\subsection{Amino acids}

Amino acids can represent up to $9 \%$ of mangrove leaf biomass (Hernes et al., 2001), but very few studies have described their composition in mangrove tissues. Zieman et al. (1984) reported concentrations of total amino acids in Rhizophora leaves of $833 \mu \mathrm{mol} \mathrm{g}^{-1}$ with glutamic acid, leucine, and glycine representing each more than $10 \%$. Avicennia leaves, on the other hand, contain mostly glycine, glutamic acid and aspartic acid (Tremblay and Benner, 2006). The concentration of amino acids tends to increase during decomposition due to microbial accumulation (Hernes et al., 2001; Tremblay and Benner, 2006). Since amino acids of prokaryote origin then become prevalent, their use as mangrove tracers appears limited.

\subsection{Tannins}

Tannins in vascular plants occur as two types, condensed and hydrolysable. They are more abundant in plant leaves than in woody tissues, and contribute to the color and astringency of the bulk organic matter. Hernes et al. (2001) found that green leaves of $R$. mangle may contain more than $6 \%$ tannins, being third in abundance after polysaccharides $(21 \%)$ and amino acids (9\%). The tannin content of mangrove leaves is higher and more polymerized than found for 40 other dicotyledonous plant species (Hernes et al., 2001). Condensed tannin consists of $80 \%$ procyanidin and $20 \%$ prodelphinidin. The latter, with its higher degree of hydroxylation, appears to be more labile than procyanidin tannin. Leaching, which induces an increase in polymerization of condensed tannin, is an important mechanism for tannin removal from leaves. Hernes et al. (2001) concluded that while the composition of brown and partly decomposed leaves is recognizable as dicotyledonous in origin, it is difficult to attribute the composition specifically to mangrove leaves.

\subsection{Lignin-derived phenols}

Lignin is a nitrogen-free co-polymer of various phenylpropenyl alcohols that is present in vascular plants. Lignin composition varies significantly between gymnosperms and angiosperms, and between hard (i.e., woods) and soft (i.e., leaves, needles) tissues. Because of the exclusive association with higher plants, lignin is usually considered as a specific tracer of terrestrial plant remains. Mangrove species exhibit a typical vascular-plant lignin signature, with great variations between leaves and wood, the latter being richer in lignin oxidation product. Marchand et al. (2005) reported a total yield of eight simple phenols ranging from 0.5 to $1.5 \%$ and from 3.8 to $5.1 \%$ of TOC in leaves and wood material, respectively. Mangrove wood is characterized by very low ratios between cinnamic phenols and vanillic phenols $(\mathrm{C} / \mathrm{V})$, whereas these ratios for mangrove leaves are an order of magnitude higher than for other dicotyledonous angiosperm leaves (Dittmar and Lara, 2001b; Marchand et al., 2005). The ratio between syringic phenols and vanillic phenols $(\mathrm{S} / \mathrm{V})$, on the other hand, is higher 
for woody tissues than for herbaceous tissues. The acid-toaldehyde ratios of both vanillic and syringic phenols in mangrove leaves are also unusually high compared to nonmangrove leaves, whereas in woody tissues, these ratios are close to zero (Opsahl and Benner, 1995; Dittmar and Lara, 2001b; Marchand et al., 2005). Lignin is generally thought to be more refractory than other molecular compounds, and Marchand et al. (2005) found that lignin-derived phenols were lost at a lower rate during decomposition than total neutral sugars and bulk organic carbon. Decomposition pathways changing the monomer ratios are known to be dependent of the redox conditions (Dittmar and Lara, 2001b; Marchand et al., 2005).

\subsection{Fatty acids}

Fatty acids are ubiquitous in living organisms, and due to their biological specificity can act as biomarkers for prokaryotes, fungi, diatoms, dinoflagellates or vascular plants. They are therefore useful tracers of the origin and flow of mangrove-derived organic carbon trough estuarine food webs. Recently, Meziane et al. (2007) showed that leaves of six mangrove species can be differentiated using their fatty acid profiles, and that geographically-separated populations of the same species can be identified. Saturated fatty acids (SAFA) dominate the fatty acid composition of mangrove leaves with Palmitic acid (16:0) as the most abundant (Sassen, 1977; Mfilinge et al., 2003, 2005; Hall et al., 2006). The high content of polyunsaturated fatty acids (PUFA), in particular 18:2 $\omega 6$ and $18: 3 \omega 3$, has been identified as useful biomarkers of mangrove leaves in estuarine food chains (Sassen, 1977; Hall et al., 2006; Meziane et al., 2007). Mangrove leaves also include the longchain fatty acids (LCFA) 24:0, 26:0 and 28:0, which are typical vascular plant markers (Alfaro et al., 2006; Hall et al., 2006; Meziane et al., 2007). Mfilinge et al. (2003) suggested that the amount of 16:0 in mangrove leaves may be an indicator of degradation state since the concentration of SAFA in detritus declines constantly with age. Conversely, the concentrations of LCFA do not change with detritus age, suggesting that these vascular plant-markers can be useful biomarkers (Mfilinge et al., 2003, 2005).

\subsection{Triterpenoids}

Pentacyclic triterpenoids have frequently been used to characterize sources of sedimentary organic matter as they are common constituents of plants. Dodd et al. (1998) reported 11 triterpenoids in epicuticular waxes accounting for up to $3.5 \%$ of Rhizophora mangle leaves from West Africa. Taraxerol (taraxer-14-en-3ß-ol) is not specific to Rhizophora but occurs in unusually high concentrations in its leaves compared to other vascular plants (Killops and Frewin, 1994; Koch et al., 2003; Versteegh et al., 2004). Taraxerol is mainly present inside the leaf, whereas $\beta$-amyrin (olean-12-en-3 $\beta$-ol) is dominant in epicuticular waxes. Leaves of Rhizophora are also characterized by high amounts of germanicol (olean-18-en-3 $\beta$-ol) and lupeol (lup-20(29)-en-3 $\beta$-ol). Avicennia germinans mainly contains betulin (lup-20(29)-en-3 $\beta, 28 \beta$-diol), lupeol and $\beta$ - sitosterol (24-ethylcholest-5-en-3 $\beta$-ol), whereas significant quantities of $\beta$-sitosterol and lupeol are typical of Laguncularia racemosa (Koch et al., 2003). Oku et al. (2003) suggested that triterpenoids may have a special function in the adaptation of mangrove to salt stress, which may explain their richness. While betulin, tracer of Avicennia, can be efficiently degraded in the sediments, taraxerol seems to be unreactive with respect to microbial degradation (Killops and Frewin, 1994; Hernes et al., 2001; Versteegh et al., 2004; Koch et al., 2005). Consequently, taraxerol can be a useful proxy for paleoenvironmental reconstructions.

\section{7. n-Alkanes}

Long-chain $n$-alkanes (between 25 and 35 carbons), that are characteristic components of epicuticular waxes of mangrove leaf surfaces, can also be used as tracers of higher plant remains (Dodd et al., 1995, 1998; Rafii et al., 1996; Versteegh et al., 2004). Versteegh et al. (2004) and Mead et al. (2005) found that the most abundant lipid at the Rhizophora leaf surface, C29nalkane, accounts for $0.22 \%$ of the dry leaf material. However, it seems that the $n$-alkanes composition in mangrove plants is susceptible to biogeographic variations. Rafii et al. (1996) and Dodd et al. (1998) reported unusually high concentration of C28n-alkane in Avicennia and Rhizophora from French Guiana, whereas C31 is also important in plants of these genera in West Africa. Foliar wax from Laguncularia racemosa in French Guiana contains, among a broad range of $n$-alkanes, high concentrations of C29 and C33 whereas this species in West Africa mostly contains C27-C29. Dodd et al. (1999) suggested that the $n$-alkane composition of mangroves can be linked to environmental conditions, and attributed the dominance of longer chained C31 and C33n-alkanes of $A$. marina in the United Arab Emirates to its evolution under arid conditions.

\section{Mangrove foodwebs and the role of fauna in organic carbon processing}

Mangrove forests are recognized as an important habitat for fauna, harboring often abundant and diverse benthic invertebrate communities (Sasekumar, 1974; Wells, 1984; Nagelkerken et al., 2008). These may further serve as important food sources for transient fauna (e.g., Sheaves and Molony, 2000) and a number of species are commercially important and are harvested for food consumption (Rönnbäck, 1999; Rönnbäck et al., 2003; Walters et al., 2008). The exact role of mangrove ecosystems in attracting and sustaining these communities has been long debated, but likely results from a combination of offering suitable habitat, food supply, and refuge from predators (e.g., Laegdsgaard and Johnson, 2001). While a general overview of mangrove food webs has recently been presented in a different context (Bouillon et al., 2008; Nagelkerken et al., 2008) and is outside the scope of this paper, we will here focus on the different food sources that may be used by mangrove benthos and the potential impact of fauna to the overall carbon budget and sediment biogeochemistry. 
Mangrove trees have traditionally been viewed as the main supplier of organic carbon to mangrove benthos, and their production was thought to fuel not only local faunal communities, but also adjacent aquatic foodwebs through outwelling (e.g., Odum and Heald, 1975). It is now recognized that the outwelling hypothesis needs to be reconsidered or at least put into perspective (see later), and recently it has been demonstrated that the view of mangrove litter as being the dominant food source in the intertidal zone is too simplified. It has become increasingly clear that mangrove invertebrates exploit a wide range of potential food resources, including mangrove litter, epiphytic algae, benthic microalgae, bacteria and fungi, as well as macroalgae and a mixture of organic sources imported from adjacent aquatic environments by tidal currents (Bouillon et al., 2002; Hsieh et al., 2002; Kieckbusch et al., 2004). Thus, the degree of utilization of mangrovederived food sources depends partially on the degree of material exchange with adjacent systems (Bouillon et al., 2004). Considering their overall abundance and high secondary productivity, consumers may have a profound impact on the overall organic carbon dynamics in mangrove systems. First, we can expect that the overall consumption rate of organic carbon (whatever its origin) is high and that selective feeding on certain food sources may significantly alter the relative amounts of different sources available for export, burial, or mineralization. Secondly, fauna process much higher amounts of material than they actually assimilate, and this can result in important modifications of the size, form or quality of the non-assimilated organic matter, which in turn may have implications for its availability for export, consumption, or mineralization.

\subsection{Qualitative importance of fauna in organic carbon dynamics}

The foraging and feeding activities of mangrove fauna can influence the properties and availability of organic carbon through a number of different mechanisms. The most wellknown example is the leaf litter removal capacity of sesarmid crabs (or the ocypodid crab Ucides cordatus in parts of the New World). Thongtham and Kristensen (2005) showed that Neoepisesarma versicolor consumes fresh green and senescent yellow Rhizophora apiculata leaves at considerably lower rate than partly degraded brown leaves. This observation is consistent with those of Giddins et al. (1986) for Neosarmatium smithii and Micheli (1993) for Sesarma messa and N. smithii. The higher palatability of brown leaves compared with green and, in particular, yellow leaves probably results from improved nutritional value and removal of inhibitory compounds by the ageing process (Poovachiranon and Tantichodok, 1991). The feeding activity of sesarmid crabs not only affects the availability of leaf litter on the forest floor and its subsequent export, but many of these crabs typically take the leaves down in their burrow for storage, where they continue to decompose (Skov and Hartnoll, 2002). Moreover, the removal of leaves from the surface is likely to be beneficial for the growth of microalgae, since these are hypothesized to be inhibited by tannins (Alongi, 1994), in which mangrove leaves are particularly rich. Sesarmid crabs ingest twice as much material than they actually assimilate (Thongtham and Kristensen, 2005), which means that half of the ingested litter subsequently becomes available as faeces for decomposer or detritus food webs. This processing of leaf material may have far-reaching consequences, since the nitrogen-rich faecal pellets are more accessible for feeding by other invertebrates due to the smaller size of the particle fragments (Lee, 1997, 1998), and have significantly higher decomposition rates compared to the original material (Lee, 1997; Kristensen and Pilgaard, 2001), resulting in a much faster turnover of organic carbon.

Deposit-feeding invertebrates such as ocypodid crabs, a range of sesarmid crabs and gastropods also process large amounts of sediment and associated organic material, which is often fed upon very selectively, either at the stage of ingestion or during assimilation (e.g., Dye and Lasiak, 1987). These selective feeding activities not only result in a modification of the amount and relative quantities of different sources of organic carbon, but also modify the sediment surface properties. Exclusion experiments have shown that grazing by epifauna significantly reduces microalgal standing stocks (Branch and Branch, 1980; Webb and Eyre, 2004; Kristensen and Alongi, 2006), which in combination with the physical modifications and disturbance of the sediment surface, may have a number of indirect effects on microbial and meiofaunal communities (Dye and Lasiak, 1986; Schrijvers et al., 1998).

A final important process through which faunal communities influence organic carbon dynamics is their burrowing activity. The resulting mixing of sediment material from different depths and the increased oxygenation around burrows results in significant local changes in the relative importance of microbial decomposition pathways (Kristensen, 2008) and enhances the reoxidation of reduced compounds (e.g. $\mathrm{Fe}^{2+}$ and $\mathrm{H}_{2} \mathrm{~S}$ ). Furthermore, burrows of crabs and other benthic fauna have been shown to significantly increase the hydraulic conductivity of mangrove sediments (Susilo et al., 2005; Mazda and Ikeda, 2006), which enhances the porewater-mediated export of dissolved nutrients and organic carbon to the aquatic environment.

\subsection{Quantitative importance of fauna on organic carbon fluxes}

Activities of mangrove fauna can have a profound quantitative impact on the availability, properties, and fate of organic matter. Leaf litter removal by crabs is not only affecting the amount of organic carbon available for export, but also the potential role of litter consumption for the overall carbon budget of mangrove systems should be stressed. This can be illustrated conceptually from scenarios where the amount of leaf litter that is potentially removed, ingested and assimilated by sesarmids feeding on a pure litter diet is estimated from literature data and a number of simple assumptions (Table 1). The essential data on biomass of sesarmids, handling rate, consumption rate and assimilation efficiency are quite variable among mangrove environments. Since the biomass of sesarmids varies widely, i.e. from 150 to 
Table 1

Conceptual scenarios showing the potential litter consumption by sesarmid crabs

\begin{tabular}{|c|c|c|c|c|c|c|}
\hline \multirow[b]{2}{*}{ Biomass of sesarmids $\left(\mathrm{g} \mathrm{m}^{-2}\right)$} & \multicolumn{2}{|c|}{ Scenario 1} & \multicolumn{2}{|c|}{ Scenario 2} & \multicolumn{2}{|c|}{ Scenario 3} \\
\hline & & & & & & \\
\hline Consumption rate $\left(\mathrm{mmol} \mathrm{C} \mathrm{m} \mathrm{m}^{-2} \mathrm{~d}^{-1}\right)$ & & & & & & \\
\hline Dependency on litter $(\%)$ & 30 & 60 & 30 & 60 & 30 & 60 \\
\hline Litter consumption in $\%$ of litterfall & 30 & 60 & 50 & 100 & 80 & 160 \\
\hline
\end{tabular}

Scenarios with "low" (1), "medium" (2) and "high" (3) crab biomass are presented. Total carbon consumption rates of sesarmid crabs are derived from the literature (see text for references). The chosen range of crab dependency of litter in the diet is based on stable isotope data presented in Bouillon et al. (2004). The fraction of the average litterfall that is potentially consumed is estimated assuming an average litter fall rate of $105 \mathrm{mmol} \mathrm{C} \mathrm{m}^{-2} \mathrm{~d}^{-1}$ (see text for more details).

$750 \mathrm{~g} \mathrm{~m}^{-2}$ (Wells, 1984; Emmerson and McGwynne, 1992; Skov and Hartnoll, 2002), three different biomass values (low, medium and high) within these limits were used here in order to provide realistic scenarios. Potential consumption rates by sesarmid crabs offered food in excess are reported to range from 500 to $1000 \mu \mathrm{mol} \mathrm{C}(\mathrm{g} \mathrm{ww} \text { crab) })^{-1} \mathrm{~d}^{-2}$ (Emmerson and McGwynne, 1992; Lee, 1998; Ólafsson et al., 2002; Gillikin et al., 2004; Thongtham and Kristensen, 2005), and an intermediate value of $700 \mu \mathrm{mol} \mathrm{C}$ (g ww crab) $)^{-1} \mathrm{~d}^{-2}$ was used in our calculations. For litter fall, a global average value of $\sim 105 \mathrm{mmol} \mathrm{C} \mathrm{m}^{-2} \mathrm{~d}^{-1}$ was used (Jennerjahn and Ittekkot, 2002 and discussion above). The exact dependency of sesarmids on mangrove litter may vary according to the species and sites considered (see above and Cannicci et al., 2008), but two values, 30 and $60 \%$ were used to cover a realistic range (Bouillon et al., 2004). The estimated fraction of leaf litter removed is highly variable (Table 1) and even a low sesarmid biomass and a low dependency on mangrove litter result in a considerable removal (30\%). When sesarmid biomass is high and their reliance on mangrove litter is also high, the average litter fall rate is insufficient to sustain sesarmids under the assumptions made. The deficit becomes even more pronounced from the fact that crabs only are capable of removing 30-90\% of the litterfall (Robertson, 1986; Micheli, 1993; Slim et al., 1997; Schories et al., 2003), while the remainder is either exported or degraded by microorganisms.

Although these calculations should be considered rather an exercise than a precise estimate, they do demonstrate that a dominant role for mangrove litter in the diet of consumers is not required to explain high litter removal rates, and hence, that the overall effect of faunal consumption on litter dynamics can be very high, even when other inputs would be the main sources sustaining faunal production. Also, under the assumptions mentioned above, food limitation might occur when relatively high densities of litter consumers are present. This has also been pointed out recently for Ucides cordatus by Nordhaus et al. (2006). They found that leaf inputs are insufficient to support the food requirements of the resident crab populations during periods of reduced litterfall. Leaf litter is clearly a major component in the diet of most sesarmid crabs (DahdouhGuebas et al., 1997), and litter carbon appears sufficient to support their growth. However, the low nitrogen availability in litter forces these crabs to obtain this element from other sources. Thongtham and Kristensen (2005) hypothesized that sesarmids primarily supplement their leaf diet by occasional ingestion of nitrogen-rich animal tissues (e.g. invertebrates and fish carcasses) since other potential nitrogen sources, such as prokaryote, fungi and benthic primary producers, only provide a limited amount of the needed nitrogen. Accordingly, Dahdouh-Guebas et al. (1999) observed that only few nonocypodid crab species from Kenyan mangrove forests are specialized plant eaters. Most of them supplement their diet with animal prey, mostly bivalves, gastropods, anomurans and other brachyurans.

Furthermore, given that the abovementioned estimates only refer to sesarmid crabs, it becomes evident that when we consider the entire community of epifauna and infauna, their impact on organic matter cycling and litter dynamics can be substantial. Data on secondary production coupled to information on resource utilization, which are entirely lacking for any mangrove system, would be required to obtain a realistic estimate of this role. The impact of fauna in current mangrove carbon budgets is often considered only in terms of direct herbivory or invoked to estimate the proportion of leaf litter retained within the system due to burial and/or consumption. Future ecosystem budgets should attempt to evaluate the potential role of resident fauna from a trophic point of view and include a wider variety of methodological approaches.

\section{Organic matter decomposition and mangrove sediment biogeochemistry}

\subsection{Early stages of decomposition}

Irrespective of the pathways and food web structure involved, all mangrove organic matter that is not exported by tidal action enters the sediment and is degraded or chemically modified by microorganisms. The decay of deposited mangrove litter begins with significant leaching of soluble organic substances. Newly-fallen mangrove litter loses $20-40 \%$ of the organic carbon by leaching when submerged in seawater for 10-14 days (Camilleri and Ribi, 1986; Twilley et al., 1997). The carbohydrates that rapidly leach after submersion in water are mostly the non-lignocellulose components (Neilson and Richards, 1989). Accordingly, Benner et al. (1990) observed that $97 \%$ of cyclitols are rapidly lost from decaying mangrove leaves. Also tannins and other phenolic compounds with microbial inhibitory potential account for a significant fraction (up to 18\%) of the dissolved organic matter (DOM) in mangrove leachate (Benner et al., 1986). This is associated with a decrease in tannin content from $59 \mathrm{mg} \mathrm{g}^{-1}$ in senescent yellow leaves to $5.5 \mathrm{mg} \mathrm{g}^{-1}$ in partly degraded brown leaves (Hernes et al., 2001). Much of the 
leached DOM is actually labile and degraded efficiently under oxic and nutrient replete conditions with conversion efficiencies into microbial biomass of up to $90 \%$ (Benner et al., 1986; Kristensen and Pilgaard, 2001). In nutrient-limited and partly anoxic mangrove sediments, on the other hand, the microbial incorporation occurs with a lower average efficiency of roughly $35 \%$ (Boto et al., 1989).

Further decomposition of the remaining particulate material occurs through extracellular enzymatic hydrolysis which is mediated by aerobic and anaerobic prokaryotes and marine mycelial decomposers such as eumycotes (fungi) and oomycotes (protoctista) (Newell, 1996). These latter organisms are highly-adapted for the capture of cellulose-rich vascular plant litter by pervasion and digestion from within. Thus, the polysaccharide (i.e. cellulosic) components of lignocellulose are generally degraded about twice as fast as the lignin component, indicating that mangrove detritus becomes relatively enriched in lignin-derived carbon with time (Benner and Hodson, 1985; Marchand et al., 2005). While cellulose and lignin can readily be degraded in oxic environments, these compounds are only slowly degraded under anoxic conditions. Lignin, for example, has a half-life of more than 150 years in anoxic mangrove sediments (Dittmar and Lara, 2001b).

The chemical changes that occur in mangrove detritus during degradation are not only caused by enzymatic cleavage and gradual loss of substances. Tremblay and Benner (2006) reported that the total hydrolysable amino acid content of leaves increases up to five-fold during a 4-year decomposition phase due to accumulation of microbial biomass. This is consistent with a general decrease in $\mathrm{C}: \mathrm{N}$ ratios observed during the decomposition of mangrove leaves (Twilley et al., 1986; Robertson, 1988; Thongtham and Kristensen, 2005). The fatty acid composition in mangrove leaves also changes from the predominantly plant dominated saturated fatty acids to monounsaturated fatty acids and branched chain fatty acids indicative of prokaryote biomass (Mfilinge et al., 2003, 2005).

The decomposition rate of newly-fallen litter has been examined in numerous litterbag studies. The decay typically follows a single exponential pattern $\left(M_{t}=\mathrm{M}_{0} \mathrm{e}^{-k t}, M_{t}\right.$ is the mass remaining after time $t, M_{0}$ is the initial mass and $k$ is the decay constant). Decay constants of yellow leaves deposited on intertidal mangrove sediment varies about two orders of magnitude (e.g. 0.001-0.1 d $\mathrm{d}^{-1}$ corresponding to a half life of 693 to 7 days) (Tam et al., 1998; Aké-Castillo et al., 2006). Although comparison among studies is complicated by methodological constraints (e.g. different mesh size in bags, pre-handling of litter and incubation time), a number of studies have shown indications of several mechanisms controlling litter degradation in mangrove environments, such as inundation frequency, abundance of detritivorous fauna, mangrove species, and the initial $\mathrm{C}: \mathrm{N}$ ratio. For instance, Middleton and McKee (2001) found from own and literature data that mangrove litter placed on frequently inundated low intertidal sediments lost on average $0.64 \pm 0.11 \% \mathrm{dw} \mathrm{d}^{-1}$, while the decay on dry upper intertidal sediments only accounted for $0.32 \pm 0.08 \% \mathrm{dw} \mathrm{d}^{-1}$. The difference is obviously caused by the greater accessibility to microbial degraders when litter is permanently wet. The role of small fauna (excluding crabs) is clearly evident from the study of Bosire et al. (2005), in which the decay of Rhizophora mucronata and Sonneratia alba litter appeared strongly dependent on the total abundance of amphipods, nematodes, turbellarians, isopods and polychaetes (Fig. 3). The shredding and macerating activities of these animals apparently increase the degradability of litter material by increasing the effective surface area accessible to microbial attack. It is obvious that the action of leaf-eating sesarmid crabs will augment this faunal effect outside litterbags where their influence is also allowed (Poovachiranon and Tantichodok, 1991; Robertson et al., 1992; Kristensen and Pilgaard, 2001).

Despite the inherent variability among litterbag studies, a number of reports have independently found an inverse relationship between the $\mathrm{C}: \mathrm{N}$ ratio of mangrove leaf litter and the decay constant. Even when these studies are combined, the relationship is still significant ( $p<0.01$, Fig. 4). Litter degradation seems therefore strongly dependent on the availability of nitrogen for the microbial decomposers. The difference in degradability and elemental composition appears to be a dual function of species (e.g. Kandelia versus Rhizophora) and location of origin (Avicennia from India versus Australia). For example, the slowly-degrading leaves of Rhizophora contain more structural lignocellulose and less nitrogen than the more labile Kandelia leaves. Leaves of $K$. candel are also rich in total fatty acids, and in essential fatty acids ( $\omega 3$ and $\omega 6$ ) entailing that they are of high nutritional quality (Mfilinge et al., 2005). The differential in elemental composition and degradability of litter from the same species between locations is probably related to the availability of nutrients in the environment. Interestingly, various aquatic plants from temperate environments (unicellular green algae and green macroalgae, as well as submerged vascular macrophytes and marsh grasses) also show an inverse relationship between elemental $\mathrm{C}: \mathrm{N}$ ratio and decay constants

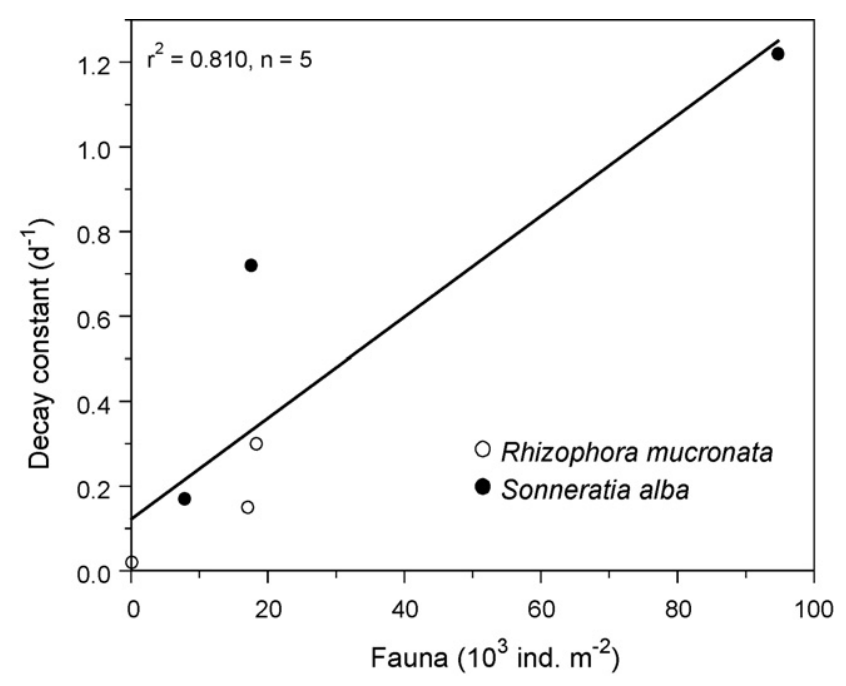

Fig. 3. Decay constants of Rhizophora mucronata and Sonneratia alba litter in litterbags as a function of benthic fauna abundance (including amphipods, nematodes, turbellarians, isopods and polychaetes, but excluding crabs). Data from Bosire et al. (2005). 


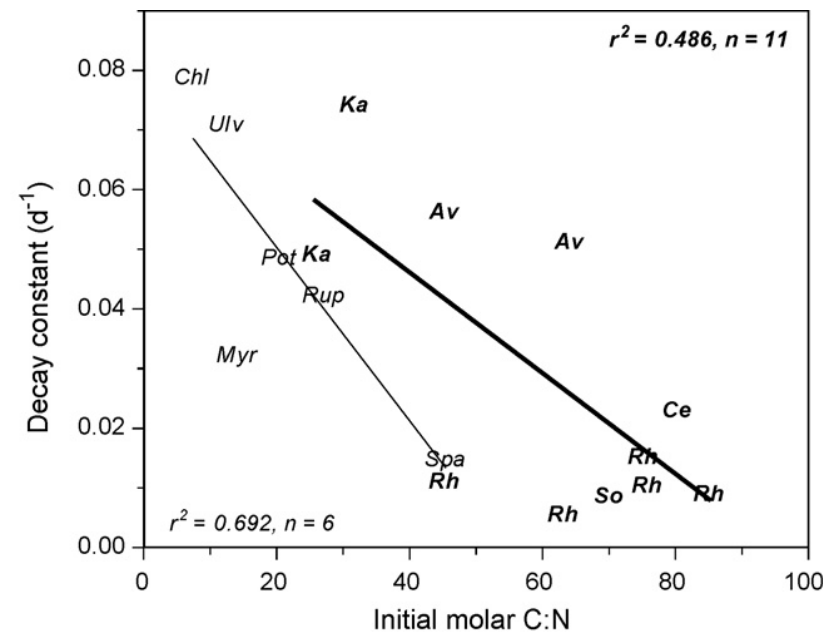

Fig. 4. Decay constants of a variety of mangrove litter (bold) and submerged macrophytes from temperate areas (light) as a function of the initial POC:TN ratio of the material. Least squares linear regression lines and correlation coefficients are shown for comparison (Twilley et al., 1986; Robertson, 1988; Twilley et al., 1997; Wafar et al., 1997; Tam et al., 1998; Mfilinge et al., 2002).

(Fig. 4). If the almost $10{ }^{\circ} \mathrm{C}$ difference in temperature between temperate and tropical incubations are considered and assuming a temperature dependence typical for biological processes (i.e. $Q_{10} \sim 2-3$ ), the two relationships are almost identical with nitrogen-rich algae decomposing fastest and nitrogen-poor mangrove litter decomposing slowest.

\subsection{Sedimentary decomposition pathways}

While the aerobic microbial community in mangrove environments consumes fresh litter and algal detritus deposited at or near the sediment surface, anaerobes are fuelled by detritus buried by accretion, by leaf-eating crabs and by belowground root production in the form of dead biomass and DOC excretions (Alongi, 1998; Kristensen and Alongi, 2006). Aerobic microorganisms have the enzymatic capacity for complete oxidation of organic carbon to $\mathrm{CO}_{2}$, while anaerobic degradation processes occur stepwise involving several competitive types of prokaryotes. Aerobic degradation of labile materials near the surface of mangrove sediments is usually so rapid that $\mathrm{O}_{2}$ rarely penetrates more than $2 \mathrm{~mm}$ into the sediment (Kristensen et al., 1994). The bulk sediment remains largely anoxic except for a network of narrow roots and infaunal burrows that translocate oxygen deep into the sediment (Kristensen and Alongi, 2006). Under anoxic conditions, large organic molecules are first split into small moieties by fermenting prokaryotes. These small molecules are then oxidized completely to $\mathrm{CO}_{2}$ by a wide variety of anaerobic microorganisms using electron acceptors in the following sequence according to the energy yield: $\mathrm{Mn}^{4+}, \mathrm{NO}_{3}{ }^{-}, \mathrm{Fe}^{3+}$ and $\mathrm{SO}_{4}{ }^{2-}$.

Aerobic respiration and anaerobic sulfate reduction are usually considered the most important respiration processes in mangrove sediments (Alongi, 1998), with a share of $40-50 \%$ each (Table 2). Consequently, most mangrove sediments contain high levels of reduced inorganic sulfur in the form of primarily pyrite $\left(\mathrm{FeS}_{2}\right)$ and elemental sulfur $\left(\mathrm{S}^{0}\right)$ and only negligible amounts of iron monosulfides (FeS) (Holmer et al., 1994). Denitrification, manganese respiration and iron respiration, on the other hand, have traditionally been considered unimportant in mangrove environments (Kristensen et al., 1998), although denitrification may be significant in areas impacted by sewage (Corredor and Morell, 1994). Recent evidence suggests, however, that the role of iron respiration in carbon oxidation may be comparable to, or higher than, sulfate reduction in iron-rich mangrove environments (Table 2). As sulfate reduction usually is hampered in the presence of more potent electron acceptors (e.g. $\mathrm{O}_{2}$ and $\mathrm{Fe}^{3+}$; Canfield et al., 2005), this process becomes inferior to iron respiration when oxidizing roots and infaunal burrows increase the $\mathrm{Fe}^{3+}$ content in mangrove sediments (Nielsen et al., 2003). Recent results have shown that the proportion of anaerobic respiration in mangrove sediments that is conducted via iron respiration (FeR) is significantly related to the concentration of reactive oxidized iron (Fe(III)) within the sediment (Fig. 5). Thus, when the concentration of reactive $\mathrm{Fe}$ (III) exceeds about $35 \mu \mathrm{mol} \mathrm{cm}{ }^{-3}$, more than $80 \%$ of the anaerobic carbon oxidation is mediated by microbial iron reduction. This relationship is strikingly similar to that generally found for other marine areas (Jensen et al., 2003).

When all electron acceptors are exhausted and electron donors are in surplus, $\mathrm{CH}_{4}$ is produced by fermentative disproportionation of low molecular compounds (e.g. acetate) or reduction of $\mathrm{CO}_{2}$ by hydrogen or simple alcohols (Canfield et al., 2005). Thus, a process like sulfate reduction can usually maintain concentrations of hydrogen and acetate at levels too low to fuel methanogens. In general, rates of methane production are low and highly variable in mangrove sediments, and in some environments the process cannot be detected at all (Alongi et al., 2004, 2005b). Despite the presence of active methanogenesis, the concentration of methane in porewaters of near-surface sediments is usually very low due to simultaneous removal by anaerobic methane oxidation (Canfield et al., 2005). Emissions of methane from mangrove sediments are therefore close to zero (range from 0 to $5 \mathrm{mmol} \mathrm{m}^{-2} \mathrm{~d}^{-1}$ ). There is a general consensus that anthropogenic influence, i.e. higher nutrient and organic loading, strongly increases emissions of methane from mangrove sediments by inducing severe oxygen stress and supplying labile organic carbon (Giani et al., 1996; Purvaja and Ramesh, 2001; Kreuzwieser et al., 2003; Alongi et al., 2005b). Nevertheless, our knowledge on factors controlling methanogenesis and methane emissions in mangrove environments is limited and relies primarily on a few recent studies.

Rates of microbial carbon oxidation and partitioning of electron acceptors within typical marine sediments are usually dependent on the quantity and reactivity of organic matter, sediment grain size, and bioturbation activity (Kristensen, 2000). However, in mangrove sediments other factors are equally important; these include forest age, physiological activities of the root system, extent of water logging and 
Table 2

Total carbon oxidation (tot $\mathrm{C}$-ox) measured as benthic $\mathrm{CO}_{2}$ release and partitioning of electron acceptors in mangrove sediments

\begin{tabular}{|c|c|c|c|c|c|c|c|}
\hline Location & Tot C-ox & $\mathrm{NO}_{3}{ }^{-}$ & $\mathrm{Mn}(\mathrm{IV})$ & $\mathrm{Fe}(\mathrm{III})$ & $\mathrm{SO}_{4}{ }^{2-}$ & $\mathrm{CH}_{4}$ prod & References \\
\hline Bangrong, Thailand & $32-62$ & $<0.1^{\mathrm{a}}$ & n.m. & $17-36$ & $5-10$ & n.m. & 1 \\
\hline Ao Nam Bor, Thailand & $54-190$ & n.m. & n.m. & n.m. & $20-46$ & n.m. & 2 \\
\hline Mekong Delta, Vietnam & $17-54$ & $0-4$ & $0.5-1.4$ & $<0.1^{\mathrm{b}}$ & $2-15$ & $\sim 0$ & 3 \\
\hline Matang, Malaysia & $77-102$ & $8-19$ & n.m. & n.m. & $39-88$ & $\sim 0$ & 4 \\
\hline Jiulongjiang, China & $67-79$ & $2-8$ & $1-18$ & $0-11^{\mathrm{b}}$ & $162-562$ & $<0.1$ & 5 \\
\hline Pichavaram, India & $106-190$ & n.m. & $1-39$ & $1-11^{\mathrm{b}}$ & $42-638$ & n.m. & 6 \\
\hline Indus Delta, Pakistan & $47-50$ & n.m. & n.m. & n.m. & $23-32$ & n.m. & 7 \\
\hline Port Hedland, Australia & $28-48$ & n.m. & $<0.1$ & $<0.1^{\mathrm{b}}$ & $11-53$ & $\sim 0$ & 8 \\
\hline Dampier, Australia & $37-51$ & n.m. & $<0.1$ & $\sim 0^{\mathrm{b}}$ & $7-28$ & $\sim 0$ & 8 \\
\hline Mangrove Bay, Australia & 29 & n.m. & $\sim 0$ & $\sim 0^{\mathrm{b}}$ & 16 & $\sim 0$ & 8 \\
\hline Bay of Rest, Australia & 33 & n.m. & $<0.1$ & $0.1^{\mathrm{b}}$ & 46 & $\sim 0$ & 8 \\
\hline Haughton, Australia & $40-93$ & n.m. & n.m. & $21-64$ & $14-24$ & n.m. & 9 \\
\hline Hinchinbrook, Australia & $2-22$ & $6-14$ & $<0.1$ & $\sim 0^{\mathrm{b}}$ & $2-20$ & $\sim 0$ & 10 \\
\hline Mtoni, Tanzania & $55-107$ & n.m. & n.m. & $27-49$ & $4-6$ & n.m. & 11 \\
\hline Ras Dege, Tanzania & $73-79$ & n.m. & n.m. & $35-57$ & $11-46$ & n.m. & 11 \\
\hline Gazi Bay, Kenya & $55-373$ & n.m. & n.m. & n.m. & n.m. & n.m. & 12 \\
\hline
\end{tabular}

The contribution (in $\mathrm{C}$ units) by independently measured anaerobic microbial carbon oxidation processes using various electron acceptors are given. Units are mmol C m${ }^{-2} \mathrm{~d}^{-1}$ (n.m.- not measured) (modified from Kristensen, 2007). References: (1) Kristensen et al. (2000); (2) Kristensen et al. (1994); (3) Alongi et al. (2000a); (4) Alongi et al. (2004); (5) Alongi et al. (2005b); (6) Alongi et al. (2005c); (7) Kristensen et al. (1992); (8) Alongi et al. (2000b); (9) Kristensen and Alongi (2006); (10) Alongi et al. (1999); (11) Kristensen (unpublished); (12) Middelburg et al. (1996).

a Obtained from the nearby Ao Nam Bor mangrove forest (Kristensen et al., 1998).

${ }^{\mathrm{b}}$ Estimated from the generation of dissolved $\mathrm{Fe}^{2+}$ only, and thereby ignoring generation of solid $\mathrm{Fe}$ (II).

intensity of faunal burrowing activities. It has been observed that sulfate reduction accounts for 20-30\% in young Avicennia marina and Rhizophora apiculata forests, while this process is responsible for most carbon oxidation in old forests (Alongi et al., 1998, 2000a). Oxidized conditions with dominance of aerobic and iron respiration prevail in sediments beneath young Rhizophora stands characterized by low plant biomass and high

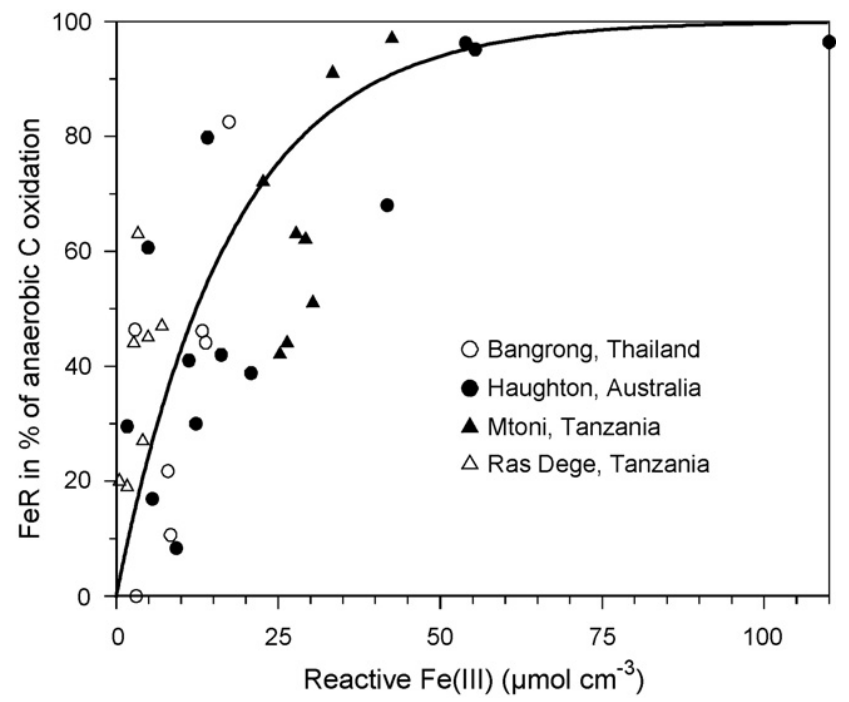

Fig. 5. Relationship between the proportion of iron respiration $(\mathrm{FeR})$ to total anaerobic carbon oxidation in mangrove sediments and the corresponding concentration of reactive Fe(III). Data are from Thailand (Kristensen et al., 2000); Australia (Kristensen and Alongi, 2006) and Tanzania (Kristensen, unpublished). Full line shows the best fit with a constant $a=0.044$ to the equation $\% \mathrm{FeR}=100(1-\exp (-a \mathrm{Fe}(\mathrm{III})))$. exposure to tidal effect on well-aerated sandy substratum. As forests age, the organic carbon input becomes stronger, and the increasing amount of fresh organic matter leads to a prevalence of sulfate reduction. The effect of Avicennia marina roots on sediment biogeochemistry, on the other hand, appears contradictive. Oxygen leaching by roots keeps the rhizosphere deep in the sediment oxidized and enriched in Fe(III) for use by iron reducers. At the same time, leaching of labile DOC from roots appears to stimulate bulk sulfate reduction (Kristensen and Alongi, 2006). The impact of water logging is evident in mature Avicennia forests. When the water table is low during the dry season, oxygen penetrates deeper into the sediment through crab burrows and cracks in the sediment and adds to the oxidizing effect of the rhizosphere, allowing suboxic (e.g. iron reduction) oxidation of organic carbon. Conversely, during the rainy season, prolonged water logging prevents oxidation of the sediment and sulfate reduction becomes the dominant pathway (Clark et al., 1998; Marchand et al., 2004). Animal burrows are a major conduit for subsurface movement of water (Ridd, 1996). They allow the supply of oxygen and oxidized elements below the depth at which oxygen usually penetrate, resulting in the development of oxidized halos around burrows (Clark et al., 1998). Thus, Kristensen et al. (2000) observed that sulfate reduction in a burrowed mudflat is reduced to half of that in adjacent vegetated and almost fauna-free sediments.

\subsection{Rates of sedimentary carbon oxidation}

The total sediment metabolism, which can be quantified as dark $\mathrm{CO}_{2}$ release, represents the sum of all aerobic and anaerobic respiration processes and provide an estimate of the total decomposition occurring within the sediment. Based on 
the available data, the global average release of $\mathrm{CO}_{2}$ from mangrove sediments in the dark is roughly $27 \mathrm{~mol} \mathrm{~m}^{-2}$ year $^{-1}$ (equivalent to $75 \mathrm{mmol} \mathrm{m}{ }^{-2} \mathrm{~d}^{-1}$ and covering a range from 2 to $373 \mathrm{mmol} \mathrm{m}^{-2} \mathrm{~d}^{-1}$ ) (Table 2). Most of these highly variable rates are probably seriously underestimated as they generally are based on flux measurements of inundated and air-exposed bare sediment away from trees and burrows. Recent measurements have shown, however, that air-exposed pneumatophores and open crab burrows increase $\mathrm{CO}_{2}$ emissions to the atmosphere considerably by efficient translocation of $\mathrm{CO}_{2}$ gas from deeper sediments. Thus, Kristensen (unpublished) found that the contribution of 100 Sonneratia alba pneumatophores $\mathrm{m}^{-2}$ is about $170 \mathrm{mmol} \mathrm{CO}_{2} \mathrm{~d}^{-1}$ and 100 Avicennia marina pneumatophores $\mathrm{m}^{-2}$ is roughly $60 \mathrm{mmol} \mathrm{CO}_{2} \mathrm{~d}^{-1}$, while $100 \mathrm{Uca}$ spp. burrows $\mathrm{m}^{-2}$ may add $90 \mathrm{mmol} \mathrm{CO}_{2} \mathrm{~d}^{-1}$ to the basic rate measured for bare sediment. In addition, respiration by the crabs themselves also contributes to $\mathrm{CO}_{2}$ loss from the sediment. A biomass of $250 \mathrm{~g}$ ww Uca spp. respires $16 \mathrm{mmol} \mathrm{CO}_{2} \mathrm{~d}^{-1}$ (Kristensen, unpublished) and the same biomass of sesarmids (Neoepisesarma versicolor) respires $21 \mathrm{mmol} \mathrm{CO}_{2} \mathrm{~d}^{-1}$ (Thongtham and Kristensen, 2005). It is therefore important that future studies on sediment metabolism in mangrove environments quantify the abundance of aerial roots and crab burrows (including crabs) and contain their contribution into the efflux of $\mathrm{CO}_{2}$ to provide reliable estimates of carbon oxidation in mangrove sediments. Such estimates may prove essential for obtaining trustworthy global carbon budgets.

\section{Burial and permanent storage of organic carbon in sediments}

Mangrove ecosystems are able to store large amounts of organic carbon (Matsui, 1998; Fujimoto et al., 1999) and in some mangrove ecosystems, organic-rich sediments of several meters depth have been found (Twilley et al., 1992; LallierVerges et al., 1998). The formation of old and refractory material in mangrove sediments can be observed visually as lignified and humified (spongy) litter fragments. Accordingly, Dittmar and Lara (2001b) estimated that the average age of organic carbon in the upper $1.5 \mathrm{~m}$ of the sediment in the Furo do Meio mangrove forest, Brazil is between 400 and 770 years. Based on a compilation of available data, Duarte and Cebrián (1996) estimated that $\sim 10 \%$ of the mangrove production is buried in the sedimentary pool, the remainder being exported ( $\sim 30 \%)$, consumed $(\sim 9 \%)$, decomposed $(\sim 40 \%)$, or unaccounted $(10 \%)$. However, the percentage of buried carbon strongly depends on the environmental conditions. As primary production increases with stand age, the efficiency of carbon burial in sediments increases, from $16 \%$ for a 5 -year-old forest to $27 \%$ for an 85-year-old stand (Alongi et al., 2004). Additionally, there is proportionally greater carbon burial in the low intertidal zone where sediment accumulation is greatest (Alongi et al., 2005b). Duarte et al. (2005) recently estimated the average global rate of carbon accumulation in mangrove systems at $10.8 \mathrm{~mol} \mathrm{~m}^{-2}$ year $^{-1}$, which is similar to the $10.7 \mathrm{~mol} \mathrm{~m}^{-2}$ year $^{-1}$ estimated by Jennerjahn and Ittekkot
(2002). There are, however, a number of caveats in such global estimates and it will likely require substantially more data to be able to constrain these budgets better.

The available global estimates of carbon accumulation are mainly calculated by difference using litter fall, export and consumption rates (Jennerjahn and Ittekkot (2002) and many of the case studies used in the approach of Duarte and Cebrián (1996)). This approach does not emphasize the fact that NPP is likely to be three to four-fold higher than the litter fall rates, which may lead to a significant underestimate of burial rates. Also, other potentially important organic carbon sources derived from tidal water, such as seagrass detritus, phytodetritus and terrestrial material (Bouillon et al., 2003; Marchand et al., 2003; Kennedy et al., 2004) are usually not considered in accumulation estimates, which may further accentuate the underestimate of carbon burial rates.

From that perspective, direct measurements of sediment and/or carbon accumulation rates hold a better potential, but unfortunately the number of such data are scarce (Chmura et al., 2003; Duarte et al., 2005) which raises the question as to whether these are representative enough for a global extrapolation. Looking into the datasets used by Duarte et al. (2005), the sediment carbon content of the mangrove sites considered was $8.5 \%$, whereas a more exhaustive data compilation indicates that a representative global estimate of carbon content is likely to be close to $2.2 \%$ (Fig. 2), suggesting that the data used in this bottom-up approach is biased towards organicrich systems and hence overestimates the global carbon accumulation in mangroves.

The close match between different approaches (Twilley et al., 1992 and references cited above) is therefore remarkable-although this does not need to imply that the carbon burial rate is well constrained, and more data need to be generated before this estimate can be confirmed or improved.

\section{Outwelling and dispersal of mangrove organic matter}

About four decades ago, Odum (1968) proposed a groundbreaking hypothesis in coastal ecology according to which the outwelling of litter from coastal wetlands is a major source of energy that supports much of the secondary production of estuaries and nearshore waters. Because of the regular tidal flooding and draining in most mangrove areas, the material exchange between the forests and coastal waters can be very efficient (e.g. Dittmar and Lara, 2001a). Many of the most productive mangrove forests in the world lose a significant fraction of their net primary production to coastal waters (Robertson et al., 1992; Jennerjahn and Ittekkot, 2002). Large differences occur between mangrove forests with respect to litter production and export rates, and some largely retain detritus within their sediments (Woodroffe, 1992), which is then mineralized or buried. On a global average, however, numerous studies indicate that mangrove forests are a significant net-source of detritus to adjacent coastal water, and the global export rate of mangrove litter has been estimated 
to be $19 \mathrm{~mol} \mathrm{C} \mathrm{m}^{-2}$ year $^{-1}$ which is approximately half of the total litter production (Jennerjahn and Ittekkot, 2002).

While there are clear patterns of high particulate detritus export in most mangrove environments, the utilization of this organic matter in marine food webs seems inconsistent. The large flux of mangrove detritus to the coastal ocean can have recognizable effects on aquatic food webs in some areas (Odum and Heald, 1975; Alongi et al., 1989; Alongi, 1990), but the litter outwelling hypothesis has been challenged in other areas (Lee, 1995; Schwamborn et al., 1999). Some studies show that, as far as particulate organic matter fluxes are concerned, mangrove forests and adjacent environments can strongly interact. For example, Hemminga et al. (1994) observed a tight coupling between mangrove forests and seagrass meadows in Gazi Bay (Kenya) where strong outwelling of particles from the mangrove environment is evident. During flood tides, however, reversed transport of organic particles from the seagrass zone to the mangrove forest can be observed. Respiratory $\mathrm{CO}_{2}$ derived from mangrove detritus can be a major inorganic carbon source for the seagrass meadows as observed by Hemminga et al. (1994) in Gazi Bay, Kenya, and Lin et al. (1991) for a mangrove-seagrass system in Florida. In contrast to the tight coupling between mangroves and adjacent seagrasses, particle outwelling is often restricted to the reef line (Schwamborn et al., 1999) while nearby coral reefs can exist in relative isolation from mangrove influence (Hemminga et al., 1994). Thus, the role of mangrove litter on sediment processes and the tight coupling with adjacent ecosystems is mostly restricted to the direct vicinity of the forests. A few kilometers offshore, however, mangrove litter usually contributes insignificantly to the organic matter accumulating in sediments or to the carbon consumed by organisms (Hemminga et al., 1994; Jennerjahn and Ittekkot, 2002).

Two major processes can explain the lack of a significant offshore impact of litter outwelling. (1) The distribution of exported mangrove litter largely depends on the local geomorphology and hydrodynamics. Many mangrove forests fringe semi-enclosed bays and estuaries. Water currents within these settings can efficiently trap suspended particles (Jay and Musiak, 1994) and cause enhanced sedimentation rates in direct vicinity of the mangrove environment. Lithogenic input from rivers can provide mineral ballast for the production of fastsinking aggregates (Jennerjahn et al., 1999). Large-scale boundary currents can also diminish the dispersion of terrigenous suspended particles off the continental margins (Jennerjahn and Ittekkot, 2002). (2) On the time-scale of outwelling, a significant fraction of litter is lost as dissolved organic carbon (DOC). Within the first weeks of litter degradation in the water column or submersed sediments, $>75 \%$ of organic carbon can be lost (Dittmar and Lara, 2001b; Schories et al., 2003), most of it to the dissolved pool (Benner et al., 1990; Wafar et al., 1997).

Mangrove-derived DOC is also released into the water column through the tidal pumping of DOC-rich porewaters, which can significantly add to the total organic carbon export (Bouillon et al., 2007b). DOC concentrations in mangrove porewaters varies considerably within and among forests, but levels as high as $9 \mathrm{mmol} \mathrm{L}^{-1}$ has been recorded (Marchand et al., 2006). Quantitative estimates from mangrove forests around the world almost consistently indicate that a significant fraction of the net carbon fixation through primary production is indeed exported to coastal waters as DOC (Boto and Wellington, 1988; Dittmar et al., 2006). Decomposition and leaching products of leaf litter are likely sources of the exported mangrove-DOC (Dittmar et al., 2001), while the contribution of root exudates or decomposing below-ground biomass is not known. The total export rate of organic carbon from mangrove forests may significantly exceed the estimates of litter export by Jennerjahn and Ittekkot $\left(2002 ; 19 \mathrm{~mol} \mathrm{C} \mathrm{m}^{-2} \mathrm{year}^{-1}\right)$ if the export of DOC is taken into account. Tidal DOC export from a Florida mangrove area (Twilley, 1985) was estimated to be 3.1-3.7 mol C m${ }^{-2}$ year $^{-1}$, while a mangrove tidal creek in Australia (Ayukai et al., 1998) exports $1.8 \mathrm{~mol} \mathrm{C} \mathrm{m}^{-2}$ year $^{-1}$, and a mangrove forest in Thailand loses $0.6 \mathrm{~mol} \mathrm{C} \mathrm{m}^{-2}$ year $^{-1}$ (Suraswadi, unpublished). These export estimates are usually based on small-scale studies performed within or in direct vicinity of the mangroves. The only study performed so far on a continental-shelf scale (Dittmar et al., 2006) indicates a significantly higher outwelling of DOC (12 $\mathrm{mol} \mathrm{C} \mathrm{m}^{-2}$ year $\left.^{-1}\right)$ compared to previous small-scale studies in the same region in northern Brazil (4 mol C m${ }^{-2}$ year $^{-1}$; Dittmar et al., 2001) or elsewhere in the world. The reason behind this discrepancy is probably that the gradual release of DOC from floating and suspended detritus in the water column was not accounted for in past studies. From the well-developed mangrove forest in Brazil about $13 \mathrm{~mol} \mathrm{C} \mathrm{m}^{-2}$ year $^{-1}$ of floating debris were exported through tidal creeks over the course of an annual sampling campaign (Schories et al., 2003). In addition to floating debris, suspended solids (POC) were exported at a rate of $3 \mathrm{~mol} \mathrm{C} \mathrm{m}^{-2}$ year $^{-1}$ (Dittmar and Lara, 2001a,c). Stable carbon isotope and lignin analyses indicated leaf litter as the primary source of the exported POC (Dittmar et al., 2001). The combined export of debris and POC accounts for $\sim 40 \%$ of the total litter fall in this mangrove forest. Mangrove-derived dissolved organic carbon (DOC) is exported at a rate of $4 \mathrm{~mol} \mathrm{C} \mathrm{m}^{-2}$ year $^{-1}$ (Dittmar and Lara, 2001c). The combined export for all organic matter fractions (debris, POC, and DOC) is $20 \mathrm{~mol} \mathrm{C} \mathrm{m}^{-2}$ year $^{-1}$. A major fraction ( $12 \mathrm{~mol} \mathrm{C} \mathrm{m}^{-2}$ year $^{-1}$ ) of this organic matter is ultimately transported across the shelf in form of DOC, probably after extensive photochemical and microbial reworking (Dittmar et al., 2006).

The release of DOC from mangrove compartments causes pronounced tidal signatures. For example, DOC concentrations in a tidal creek in northern Brazil that drains a well-developed mangrove area showed a pronounced tidal pattern (Dittmar and Lara, 2001a; Fig. 6). During ebb, DOC-rich porewater seeps out of the mangrove sediments and the concentrations sharply increase. The molecular lignin signature of this DOM showed that degradation products of mangrove detritus (mainly $R$. mangle and A. germinans litter) are the main source of DOC seeping out of the sediments (Dittmar et al., 2001). In a very similar fashion, DOC concentrations were found to fluctuate according to the tides in a pristine mangrove creek in Tanzania 


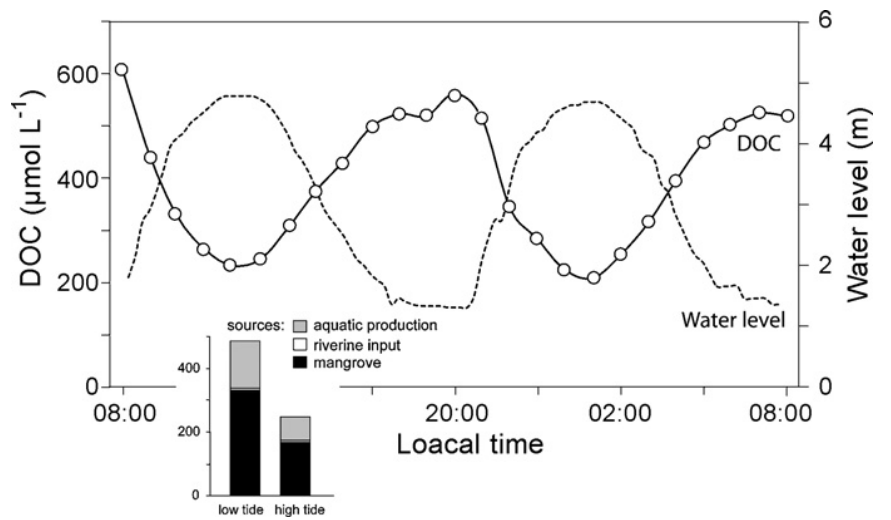

Fig. 6. An example of a 24-h time-series of DOC and water level in a tidal creek that drains about $2.2 \mathrm{~km}^{2}$ of a well-developed mangrove forest in tropical Brazil (Bragança) during the rainy season (29-30 May, 1997; Dittmar and Lara, 2001a). Source assignment of DOC was made with a molecular lignin approach (Dittmar et al., 2001). Annual average values $(n=17)$ are shown for low and high tide.

(Fig. 7; Bouillon et al., 2007b). There, two major sources of DOM could be distinguished. The stable carbon isotope composition of DOC closely followed the tidal cycle, and indicated inputs of ${ }^{13} \mathrm{C}$-enriched (seagrass) material into the mangrove during flood tide, and ${ }^{13} \mathrm{C}$-depleted mangrove DOM leaving the system during ebb tide.

Important master variables that control to a large degree the magnitude of organic matter outwelling and the partition between debris, POC and DOC outwelling are net primary production, the abundance of litter-collecting fauna and tidal range. In the mangrove forest of Bragança (northern Brazil), the leaf-removing crab Ucides cordatus has a key-role for leaf-litter turnover, significantly impacting litter export and decomposition (Schories et al., 2003). The main vehicle for DOC outwelling is tidally induced porewater flow from the upper sediment and litter horizon (Dittmar and Lara, 2001a) which is largely controlled by tidal range.

Little is known about the fate of mangrove-derived DOC in the ocean. The bulk of the leachable fraction from $R$. mangle leaves can be mineralized rapidly and assimilated into microbial biomass (Benner and Hodson, 1985). A significant fraction of mangrove-derived DOC, however, is relatively

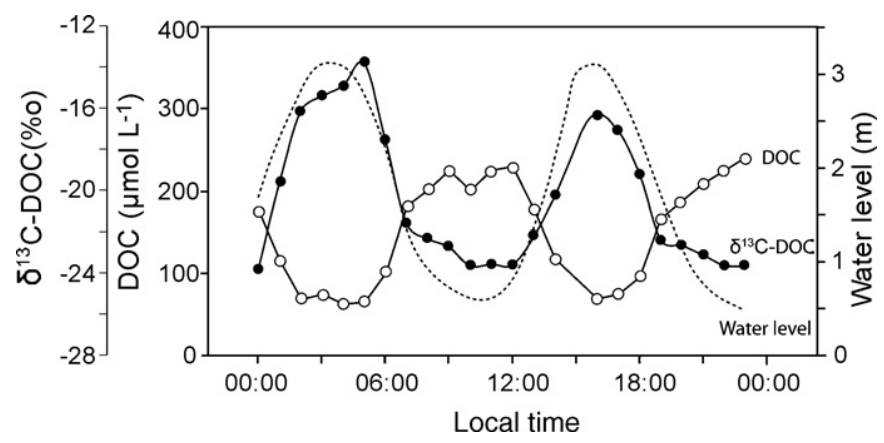

Fig. 7. Example of 24-h time-series of DOC, $\delta^{13} \mathrm{C}$ of DOC and water level in a tidal creek that drains about $2.2 \mathrm{~km}^{2}$ of a pristine mangrove forest (Ras Dege) in Tanzania during the dry season (16-17 September, 2005) (Bouillon et al., 2007b). resistant to degradation. Photodegradation and bio-incubation experiments indicate that a substantial fraction $(\sim 50 \%)$ of the DOC in mangrove porewater is refractory on a time-scale of weeks to years. Thus, it may be distributed over larger distances on continental shelves and beyond, depending mainly on the local hydrodynamics at the sites of export. Slow mineralization of mangrove-DOC could fuel aquatic (secondary) production far away from the mangrove areas, giving reason to revive the original outwelling hypothesis in a modified form. On the North Brazil Shelf, mixing diagrams (Fig. 8a) indicate a strong brackish water source of DOC. Stable carbon isotope analyses confirm that mangroves, including microbial secondary products, are the prime source of this DOC (Dittmar et al., 2006). Mangrove-derived DOC is present on the North Brazil Shelf at distances $>100 \mathrm{~km}$ offshore. Mixing diagrams from a mangrove-fringed creek in Tanzania show a strong source of DOC at high salinity (Fig. 8b; Bouillon et al., 2007b), i.e. due to highly saline porewater intrusion at low tide and sedimentwater exchange during tidal inundation. Mangrove-derived DOC in this porewater appeared to mix conservatively with low-DOC waters, which suggests a refractory nature of mangrove-DOC in this system over the time frame of the water residence time (estimated at 2-3 days, M.R. Flindt, pers. comm.). Refractory properties are a prerequisite for further dispersion on continental shelves.

Mangroves probably contribute $>10 \%$ of the terrestriallyderived, refractory DOC transported to the ocean (Dittmar et al., 2006), while they cover only $<0.1 \%$ of the continents' surface. Organic carbon export from mangrove areas to the ocean is more than one order of magnitude higher in proportion to their net-primary production than any major river (Fig. 9). The rapid decline in mangrove cover over the recent decades (Valiela et al., 2001) may have significantly impacted the flux of terrigenous DOC to the ocean.

\section{Perspectives and research directions}

Over the past two decades, a large number of case studies have significantly increased our knowledge on carbon dynamics in mangrove systems and on the importance of various biogeochemical processes. We still lack, however, a complete understanding of the underlying mechanisms controlling the spatial and temporal variability of these processes as a function of changes in environmental conditions. Vegetation type, faunal composition, microbial processes and sediment structure changes along tidal elevation gradients, and range from more marine influenced communities near the seaward edge to a significant terrestrial imprint at the higher elevations (hundreds of meter to kilometre scales). The variability in carbon transformations and transport conditions among mangrove environments is affected by specific local conditions with respect to climate, degree of exposure to strong water movement, the vicinity of river discharges, soil and bedrock composition in the neighboring terrestrial system and, not the least, the local vegetation and fauna. Due to such inherent environmental variability combined with the rather limited data available, generalizations on a global scale become 

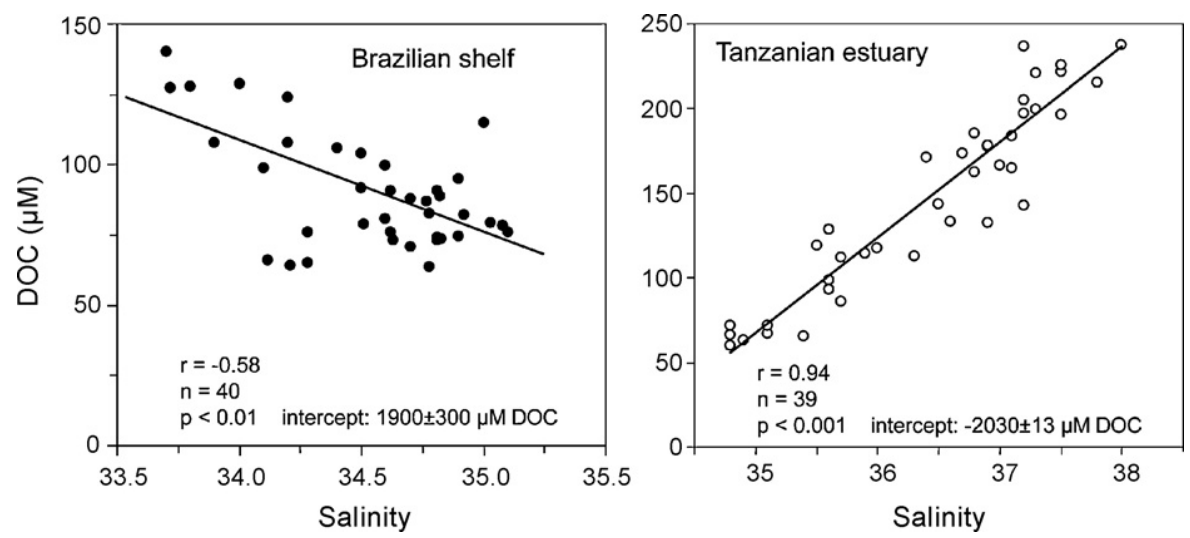

Fig. 8. Mixing diagrams of DOC concentrations on the mangrove-fringed North Brazilian shelf (October-November 2001; Dittmar et al., 2006) and a mangrove tidal creek in Tanzania (Ras Dege; September 2005; Bouillon et al., 2007b).

troublesome, and future progress can only be made by significantly increasing the spatial and temporal components of our database.

The characterization of the molecular composition of mangrove tissues (and other organic matter sources) has been much refined, and the further development of tracer techniques combined with molecular and isotope approaches can therefore be expected to offer exciting opportunities to trace mangrovederived organic matter in much more detail than was previously possible. This should contribute to our understanding of past ecosystem changes as well as the functioning of contemporary mangrove systems. However, in order to better constrain mangrove carbon budgets and the impact of mangroves on the coastal ocean, a better appraisal of mangrove net primary productivity is crucial, in particular a more robust set of data on wood and belowground production. Additionally, more studies on organic matter preservation (e.g. incorporation of sulfur within the organic matter or adsorption onto clay minerals) are

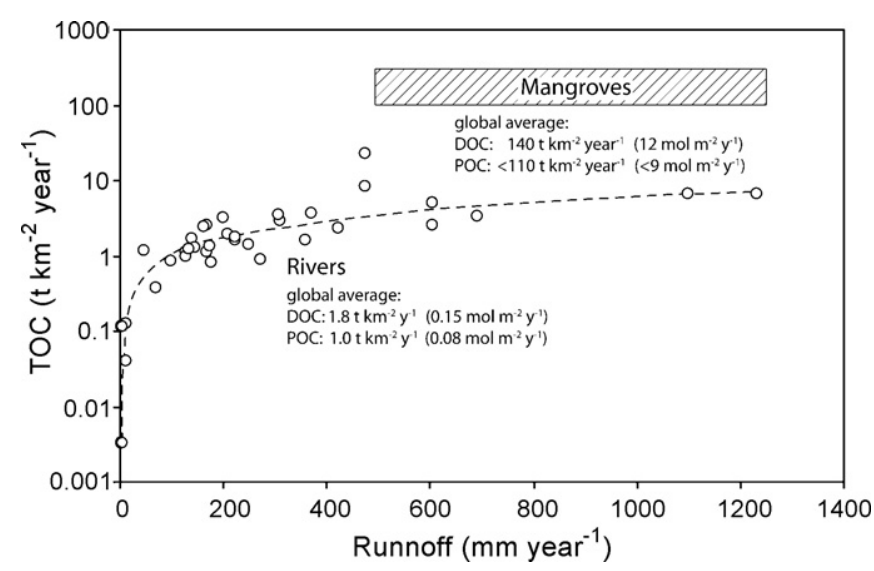

Fig. 9. Comparison between the area-normalized organic carbon runoff from mangrove forests (DOC: Dittmar et al., 2006) and major world rivers (Spitzy and Leenheer, 1991) from all climate zones draining a variety of continental biomes. POC export rates from mangrove forests assume that more than $50 \%$ of the reported litter export (Jennerjahn and Ittekkot, 2002) is rapidly lost to the DOC pool and/or assimilated and not exported as suspended or floating matter off the inner-coastal zone (see text for details). needed to better constrain the type of organic matter that is buried in mangrove sediments and to allow for a more precise interpretation of sediment core data to reconstruct past mangrove environments.

Mangrove ecosystems are being converted or degraded at alarming rates, and we have already witnessed major losses worldwide. Given the high potential impact of mangroves on sedimentation of riverine suspended matter, and on exchange of organic matter and nutrients with coastal waters, such high losses or severe degradation of their functioning can be expected to coincide with important changes in coastal zone carbon budgets. Efforts to conserve and restore mangrove forests are being conducted in many different areas, and one important aspect in assessing the success of these efforts is to verify the extent to which restored or replanted sites function similarly to pristine sites, both in terms of their habitat function for faunal communities (e.g., Bosire et al., 2004, 2008), and in terms of their productivity and biogeochemical functioning (McKee and Faulkner, 2000; Bosire et al., 2005). A sound knowledge on biogeochemical processes and the factors influencing carbon dynamics in natural systems is of prime importance in enabling a proper evaluation of the restoration success (McKee and Faulkner, 2000; Bosire et al., 2008). Mangroves are also under increasing stress from anthropogenic pollution and nutrient inputs, and have been considered efficient systems for the removal of nutrients and other anthropogenic pollutants (e.g., Tam and Wong, 1993). Here, too, a more fundamental understanding of nutrient cycling and factors influencing the nutrient processing pathways will be important in enabling us to determine the carrying capacity of these ecosystems and the long-term response to inevitable further increased inputs of nutrients in tropical coastal ecosystems.

\section{Acknowledgements}

Financial support was provided by the Danish Science Research Council (Grant\# 21020463), the Research Foundation Flanders (FWO-Vlaanderen) and the EU-project PUMPSEA (FP6 - INCO contract no. 510863). This is publication 4225 of the Netherlands Institute of Ecology (NIOO-KNAW). 


\section{References}

Aké-Castillo, J., Vázquez, G., López-Portillo, J., 2006. Litterfall and decomposition of Rhizophora mangle L. in a coastal lagoon in the southern Gulf of Mexico. Hydrobiologia 559, 101-111.

Alfaro, A.C., Thomas, F., Sergent, L., Duxbury, M., 2006. Identification of trophic interactions within an estuarine food web (northern New Zealand) using fatty acid biomarkers and stable isotopes. Estuar. Coast. Shelf Sci. 70, 271-286.

Alongi, D.M., 1990. Abundances of benthic microfauna in relation to outwelling of mangrove detritus in a tropical coastal region. Mar. Ecol. Prog. Ser. 63, 53-63.

Alongi, D.M., 1994. Zonation and seasonality of benthic primary production and community respiration in tropical mangrove forests. Oecologia 98, 320-327.

Alongi, D.M., 1998. Coastal Ecosystem Processes. CRC Press, p. 419.

Alongi, D.M., 2007. The contribution of mangrove ecosystems to global carbon cycling and greenhouse gas emissions. In: Tateda, Y., UpstillGoddard, R., Goreau, T., Alongi, D., Nose, A., Kristensen, E., Wattayakorn, G. (Eds.), Greenhouse Gas and Carbon Balances in Mangrove Coastal Ecosystems. Maruzen, Tokyo, pp. 1-10.

Alongi, D.M., Boto, K.G., Tirendi, F., 1989. Effect of exported mangrove litter on bacterial productivity and dissolved organic carbon fluxes in adjacent tropical nearshore sediments. Mar. Ecol. Prog. Ser. 56, 133-144.

Alongi, D.M., Clough, B.F., Robertson, A.I., 2005a. Nutrient-use efficiency in arid-zone forests of the mangroves Rhizophora stylosa and Avicennia marina. Aquat. Bot. 82, 121-131.

Alongi, D.M., Dixon, P., 2000. Mangrove primary production and above and below-ground biomass in Sawi Bay, southern Thailand. Phuket Mar. Biol. Center. Spec. Publ. 22, 31-38.

Alongi, D.M., Tirendi, F., Trott, L.A., Xuan, T.T., 2000a. Benthic decomposition rates and pathways in plantations of the mangrove Rhizophora apiculata in the Mekong delta. Vietnam Mar. Ecol. Prog. Ser. 194, 87-101.

Alongi, D.M., Pfitzner, J., Trott, L.A., Tirendi, F., Dixon, P., Klumpp, D.W., 2005b. Rapid sediment accumulation and microbial mineralization in forests of the mangrove Kandelia candel in the Jiulongjiang Estuary, China. Estuar. Coast. Shelf Sci. 63, 605-618.

Alongi, D.M., Ramanathan, A.L., Kannan, L., Tirendi, F., Trott, L.A., Bala Krishna Prasad, M., 2005c. Influence of human-induced disturbance on benthic microbial metabolism in the Pichavaram mangroves, Vellar-Coleroon complex, India. Mar. Biol. 147, 1033-1044.

Alongi, D.M., Sasekumar, A., Tirendi, F., Dixon, P., 1998. The influence of stand age on benthic decomposition and recycling of organic matter in managed mangrove forests of Malaysia. J. Exp. Mar. Biol. Ecol. 225, 197 218 .

Alongi, D.M., Sasekumar, A., Chong, V.C., Pfitzner, J., Trott, L.A., Tirendi, F., Dixon, P., Brunskill, G.J., 2004. Sediment accumulation and organic material flux in a managed mangrove ecosystem: estimates of landocean-atmosphere exchange in peninsular Malaysia. Mar. Geol. 208, $383-402$.

Alongi, D.M., Tirendi, F., Clough, B.F., 2000b. Below-ground decomposition of organic matter in forests of the mangroves Rhizophora stylosa and Avicennia marina along the arid coast of Western Australia. Aquat. Bot. 68, $97-$ 122.

Alongi, D.M., Tirendi, F., Dixon, P., Trott, L.A., Brunskill, G.J., 1999. Mineralization of organic matter in intertidal sediments of a tropical semienclosed delta. Estuar. Coast. Shelf Sci. 48, 451-467.

Ayukai, T., Miller, D., Wolanksi, E., Spagnol, S., 1998. Fluxes of nutrients and dissolved and particulate organic matter in two mangrove creeks in northeastern Australia. Mangr. Salt Marshes 2, 223-230.

Benner, R., Hodson, R.E., 1985. Microbial degradation of the leachable and lignocellulosic components of leaves and wood from Rhizophora mangrove in a tropical mangrove swamp. Mar. Ecol. Prog. Ser. 23, 221-230.

Benner, R., Weliky, K., Hedges, J.I., 1990. Early diagenesis of mangrove leaves in a tropical estuary: molecular-level analyses of neutral sugars and lignin derived phenols. Geochim. Cosmochim. Acta 54, 1991-2001.

Benner, R., Peele, E.R., Hodson, R.E., 1986. Microbial utilization of dissolved organic matter from leaves of the Red Mangrove, Rhizophora mangle, in the Fresh creek estuary. Bahamas Estuar. Coast. Shelf Sci. 23 607-619.

Borges, A.V., Djenidi, S., Lacroix, G., Théate, J., Delille, B., Frankignoulle, M. 2003. Atmospheric $\mathrm{CO}_{2}$ flux from mangrove surrounding waters. Geophys. Res. Lett. 30, 1558.

Bosire, J.O., Dahdouh-Guebas, F., Kairo, J.G., Kazungu, J., Dehairs, F., Koedam, N., 2005. Litter degradation and $\mathrm{CN}$ dynamics in reforested mangrove plantations at Gazi Bay, Kenya. Biol. Conserv. 126, 287-295.

Bosire, J., Dahdouh-Guebas, F., Kairo, J.G., Cannicci, S., Koedam, N., 2004. Spatial variations in macrobenthic fauna recolonisation in a tropical mangrove bay. Biodiv. Conserv. 13, 1059-1074.

Bosire, J.O., Dahdouh-Guebas, F., Walton, M., Crona, B.I., Lewis III, R.R., Field, C., Kairo, J.G., Koedam, N., 2008. Functionality of restored mangroves: A review. Aquat. Bot. 89, 251-259.

Boto, K.G., Wellington, J.T., 1988. Seasonal variations in concentrations and fluxes of dissolved organic and inorganic materials in a tropical, tidallydominated, mangrove waterway. Mar. Ecol. Prog. Ser. 50, 151-160.

Boto, K.G., Alongi, D.M., Nott, A.L.J., 1989. Dissolved organic carbonbacteria interactions at sediment-water interface in a tropical mangrove system. Mar. Ecol. Prog. Ser. 51, 243-251.

Bouillon, S., Koedam, N., Raman, A.V., Dehairs, F., 2002. Primary producers sustaining macro-invertebrate communities in intertidal mangrove forests. Oecologia 130, 441-448.

Bouillon, S., Dahdouh-Guebas, F., Rao, A.V.V.S., Koedam, N., Dehairs, F., 2003. Sources of organic carbon in mangrove sediments: variability and possible ecological implications. Hydrobiologia 495, 33-39.

Bouillon, S., Moens, T., Overmeer, I., Koedam, N., Dehairs, F., 2004. Resource utilization patterns of epifauna from mangrove forests with contrasting inputs of local versus imported organic matter. Mar. Ecol. Prog. Ser. 278, 77-88.

Bouillon, S., Dehairs, F., Schiettecatte, L.-S., Borges, A.V., 2007a. Biogeochemistry of the Tana estuary and delta (northern Kenya). Limnol. Oceanogr. 52, 46-59.

Bouillon, S., Middelburg, J.J., Dehairs, F., Borges, A.V., Abril, G., Flindt, M., Ulomi, S., Kristensen, E., 2007b. Importance of intertidal sediment processes and porewater exchange on the water column biogeochemistry in a pristine mangrove creek (Ras Dege, Tanzania). Biogeosciences 4, 311-322.

Bouillon, S., Connolly, R., and Lee, S.Y., 2008. Carbon exchange and cycling in mangrove ecosystems: a synthesis of recent insights based on stable isotope studies, J. Sea Res., doi:10.1016/j.seares.2007.05.001, in press.

Branch, G.M., Branch, M.L., 1980. Competition in Bembicium auratum (Gastropoda) and its effect on microalgal standing stocks in mangrove muds. Oecologia 46, 106-114.

Camilleri, J.C., Ribi, G., 1986. Leaching of dissolved organic carbon (DOC) from dead leaves, formation of flakes from DOC, and feeding on flakes by crustaceans in mangroves. Mar. Biol. 91, 337-344.

Canfield, D.E., Kristensen, E., Thamdrup, B., 2005. Aquatic Geomicrobiology. Elsevier, Amsterdam, p. 640.

Cannicci, S., Burrows, D., Fratini, S., Smith III, T.J., Offenberg, J., DahdouhGuebas, F., 2008. Faunistic impact on vegetation structure and ecosystem function in mangrove forests: A review. Aquat. Bot. 89, 186-200.

Chmura, G.L., Anisfeld, S.C., Cahoon, D.R., Lynch, J.C., 2003. Global carbon sequestration in tidal, saline wetland soils. Glob. Biogeochem. Cycles 17 (4), 1111.

Clark, M.W., McConchie, D., Lewis, D.W., Saenger, P., 1998. Redox stratification and heavy metal partitioning in Avicennia-dominated mangrove sediments: a geochemical model. Chem. Geol. 149, 147-171.

Corredor, J.E., Morell, J.M., 1994. Nitrate depuration of secondary sewage effluents in mangrove sediments. Estuaries 17, 295-300.

Dahdouh-Guebas, F., Giuggioli, M., Oluoch, A., Vannini, M., Cannicci, S., 1999. Feeding habits of non-ocypodid mangrove crabs from Kenya. Bull. Mar. Sci. 64, 291-297.

Dahdouh-Guebas, F., Verneirt, M., Tack, J.F., Koedam, N., 1997. Food preferences of Neosarmatium meinerti de Man (Decapoda: Sesarminae) and its possible effect on the regeneration of mangroves. Hydrobiologia 347, 83-89.

Day, J.W., Connor, W.H., Leylou, F., Day, R.H., Navarro, A.M., 1987. The productivity and composition of mangrove forests, Laguna de Terminos, Mexico. Aquat. Bot. 27, 267-284. 
Dittmar, T., Lara, R.J., 2001a. Driving forces behind nutrient and organic matter dynamics in a mangrove tidal creek in north Brazil. Estuar. Coast. Shelf Sci. 52, 249-259.

Dittmar, T., Lara, R.J., 2001b. Molecular evidence for lignin degradation in sulfate reducing mangrove sediments (Amazônia, Brazil). Geochim. Cosmochim. Acta 65, 1403-1414.

Dittmar, T., Lara, R.J., 2001c. Do mangroves rather than rivers provide nutrients to coastal environments south of the Amazon River? Evidence from longterm flux measurements. Mar. Ecol. Prog. Ser. 213, 67-77.

Dittmar, T., Lara, R.J., Kattner, G., 2001. River or mangrove? Tracing major organic matter sources in tropical Brazilian coastal waters. Mar. Chem. 73, 253-271.

Dittmar, T., Hertkorn, N., Kattner, G., Lara, R.J., 2006. Mangroves, a major source of dissolved organic carbon to the oceans. Glob. Biogeochem. Cycles 20 , doi:10.1029/2005GB002570.

Dodd, R.S., Fromard, F., Rafii, Z.A., Blasco, F., 1995. Biodiversity among west African Rhizophora: foliar wax chemistry. Biochem. System. Ecol. 23, 859868.

Dodd, R.S., Rafii, Z.A., Fromard, F., Blasco, F., 1998. Evolutionary diversity among Atlantic coast mangroves. Acta Oecol. 19, 323-330.

Dodd, R.S., Blasco, F., Rafii, Z.A., Torquebiau, E., 1999. Mangroves of the United Arab Emirates: ecotypic diversity in cuticular waxes at the bioclimatic extreme. Aquat. Bot. 63, 291-304.

Duarte, C.M., Cebrián, J., 1996. The fate of marine autotrophic production. Limnol. Oceanogr. 41, 1758-1766.

Duarte, C.M., Middelburg, J.J., Caraco, N., 2005. Major role of marine vegetation on the oceanic carbon cycle. Biogeosciences 2, 1-8.

Dye, A.H., Lasiak, T.A., 1986. Microbenthos, meiobenthos and fiddler crabs: trophic interactions in a tropical mangrove sediment. Mar. Ecol. Prog. Ser. 32, 259-267.

Dye, A.H., Lasiak, T.A., 1987. Assimilation efficiencies of fiddler crabs and deposit-feeding gastropods from tropical mangrove sediments. Comp. Biochem. Physiol. 87A, 341-344.

Emmerson, W.D., McGwynne, L.E., 1992. Feeding and assimilation of mangrove leaves by the crab Sesarma meinerti de Man in relation to leaf-litter production in Mgazana, a warm-temperate southern African mangrove swamp. J. Exp. Mar. Biol. Ecol. 157, 41-53.

Fratini, S., Cannicci, S., Vannini, M., 2000. Competition and interaction between Neosarmatium meinerti (Crustacea: Grapsidae) and Terebralia palustris (Mollusca: Gastropoda) in a Kenyan mangrove. Mar. Biol. 137, 309-316.

Fujimoto, K., Imaya, A., Tabuchi, R., Kuramoto, S., Utsugi, H., Murofushi, T., 1999. Belowground carbon storage of Micronesian mangrove forests. Ecol. Res. 14, 409-413.

Furukawa, K., Wolanski, E., Mueller, H., 1997. Currents and sediment transport in mangrove forests. Estuar. Coast. Shelf Sci. 44, 301-310.

Gattuso, J.P., Frankignoulle, M., Wollast, R., 1998. Carbon and carbonate metabolism in coastal aquatic ecosystems. Annu. Rev. Ecol. Syst. 29, 405434.

Giani, L., Bashan, Y., Holguin, G., Strangmann, A., 1996. Characteristics and methanogenesis of the Balandra lagoon mangrove soils, Baja California Sur. Mexico Geoderma 72, 149-160.

Giddins, R.L., Luscas, J.S., Neilson, M.J., Richards, G.N., 1986. Feeding ecology of the mangrove crab Neosarmatium smithi (Crustacea: Decapoda: Sesarmidae). Mar. Ecol. Prog. Ser. 33, 147-155.

Gillikin, D.P., De Wachter, B., Tack, J.F., 2004. Physiological response of two ecologically important Kenyan mangrove crabs exposed to altered salinity regimes. J. Exp. Mar. Biol. Ecol. 301, 93-109.

Giraldo Sánchez, B., 2005. Belowground productivity of mangrove forests in southwest Florida. Ph.D. thesis, Lousiana State University, 181 pp.

Hall, D., Lee, S.Y., Meziane, T., 2006. Fatty acids as trophic tracers in an experimental estuarine food chain: Tracer transfer. J. Exp. Mar. Biol. Ecol. 336, 42-53.

Hemminga, M.A., Slim, F.J., Kazungu, J., Ganssen, G.M., Nieuwenhuize, J., Kruyt, N.M., 1994. Carbon outwelling from a mangrove forest with adjacent seagrass beds and coral reefs (Gazi Bay, Kenya). Mar. Ecol. Prog. Ser. 106, 291-301.

Hernes, P.J., Benner, R., Cowie, G.L., Goni, M.A., Bergamaschi, B.A., Hedges, J.I., 2001. Tannin diagenesis in mangrove leaves from a tropical estuary: A novel molecular approach. Geochim. Cosmochim. Acta 65, 31093122 .

Holmer, M., Kristensen, E., Banta, G., Hansen, K., Jensen, M.H., Bussawarit, N., 1994. Biogeochemical cycling of sulfur and iron in sediments of a southeast Asian mangrove, Phuket Island, Thailand. Biogeochemistry 26, 145161 .

Holmer, M., Anderson, F.Ø., Holmboe, N., Kristensen, E., Thongtham, N., 2001. Spatial and temporal variability in benthic processes along a mangrove-seagrass transect near the Bangrong Mangrove, Thailand. Wetlands Ecol. Manag. 9, 141-158.

Hsieh, H.L., Chen, C.P., Chen, Y.G., Yang, H.H., 2002. Diversity of benthic organic matter flows through polychaetes and crabs in a mangrove estuary: $\delta^{13} \mathrm{C}$ and $\delta^{34} \mathrm{~S}$ signals. Mar. Ecol. Prog. Ser. 227, 145-155.

Jay, D.A., Musiak, J.D., 1994. Particle trapping in estuarine tidal flows. J. Geophys. Res. 99, 20445-20461.

Jennerjahn, T.C., Ittekkot, V., Carvalho, C.E.V., Ovalle, A.R.C., Rezende, C. E., Erlenkeuser, H., 1999. Temporal variability of amino acid, hexosamine and carbohydrate fluxes on the eastern Brazilian continental margin related to discharge of the São Francisco River, Brazil. In: Knoppers, B., Ekau, W. (eds.) JOPS-II: sedimentation process at East and Northeast Brazil Shelf. Geo.-Mar. Lett. 19, 202-208.

Jennerjahn, T.C., Ittekkot, V., 2002. Relevance of mangroves for the production and deposition of organic matter along tropical continental margins. Naturwissenschaften 89, 23-30.

Jensen, M.M., Thamdrup, B., Rysgaard, S., Holmer, M., Fossing, H., 2003. Rates and regulation of microbial iron reduction in sediments of the BalticNorth Sea transition. Biogeochemistry 65, 295-317.

Kennedy, H., Gacia, E., Kennedy, D.P., Papadimitriou, S., Duarte, C.M., 2004. Organic carbon sources to SE Asian coastal sediments. Estuar. Coast. Shelf Sci. 60, 59-68.

Kieckbusch, D.K., Koch, M.S., Serafy, J.E., Anderson, W.T., 2004. Trophic linkages among primary producers and consumers in fringing mangroves of subtropical lagoons. Bull. Mar. Sci. 74, 271-285.

Killops, S.D., Frewin, N.L., 1994. Triterpenoid diagenesis and cuticular preservation. Org. Geochem. 21, 1193-1209.

Kitheka, J.U., Ongwenyi, G.S., Mavuti, K.M., 2002. Dynamics of suspended sediment exchange and transport in a degraded mangrove creek in Kenya. Ambio 31, 580-587.

Koch, M.S., Madden, C.J., 2001. Patterns of primary production and nutrient availability in a Bahamas lagoon with fringing mangroves. Mar. Ecol. Prog. Ser. 219, 109-119.

Koch, B.P., Rullkötter, J., Lara, R.J., 2003. Evaluation of triterpenols and sterols as organic matter biomarkers in a mangrove ecosystem in northern Brazil. Wetl. Ecol. Manag. 11, 257-263.

Koch, B.P., Harder, J., Lara, R.J., Kattner, G., 2005. The effect of selective microbial degradation on the composition of mangrove derived pentacyclic triterpenols in surface sediments. Org. Geochem. 36, 273-285.

Kreuzwieser, J., Buchholz, J., Rennenberg, H., 2003. Emisson of methane and nitrous oxide by Australian mangrove ecosystems. Plant Biol. 5, 423-431.

Kristensen, E., 2000. Organic matter diagenesis at the oxic/anoxic interface in coastal marine sediments, with emphasis on the role of burrowing animals. Hydrobiologia 426, 1-24.

Kristensen, E., 2008. Mangrove crabs as ecosystem engineers, with emphasis on sediment processes. J. Sea Res., doi:10.1016/j.seares.2007.05.004, in press.

Kristensen, E., 2007. Carbon balance in mangrove sediments: the driving processes and their controls. In: Tateda, Y., Upstill-Goddard, R., Goreau, T., Alongi, D., Nose, A., Kristensen, E., Wattayakorn, G. (Eds.), Greenhouse Gas and Carbon Balances in Mangrove Coastal Ecosystems. Maruzen, Tokyo, pp. 61-78.

Kristensen, E., Suraswadi, P., 2002. Carbon, nitrogen and phosphorus dynamics in creek water of a Southeast Asian mangrove forest. Hydrobiologia 474, 197-211.

Kristensen, E., Alongi, D.M., 2006. Control by fiddler crabs (Uca vocans) and plant roots (Avicennia marina) on carbon, iron and sulfur biogeochemistry in mangrove sediment. Limnol. Oceanogr. 51, 1557-1571.

Kristensen, E., Devol, A.H., Ahmed, S.I., Saleem, M., 1992. Preliminary study of benthic metabolism and sulfate reduction in a mangrove swamp of the Indus Delta, Pakistan. Mar. Ecol. Prog. Ser. 90, 287-297. 
Kristensen, E., King, G.M., Holmer, M., Banta, G.T., Jensen, M.H., Hansen, K., Bussarawit, N., 1994. Sulfate reduction, acetate turnover and carbon metabolism in sediments of the Ao-Nam-Bor mangrove, Phuket, Thailand. Mar. Ecol. Prog. Ser. 109, 245-255.

Kristensen, E., Jensen, M.H., Banta, G.T., Hansen, K., Holmer, M., King, G.M., 1998. Transformation and transport of inorganic nitrogen in sediments of a southeast Asian mangrove forest. Aquat. Microb. Ecol. 15, 165-175.

Kristensen, E., Andersen, F.Ø., Holmboe, N., Holmer, M., Thongtham, N., 2000. Carbon and nitrogen mineralization in sediments of the Bangrong mangrove area, Phuket, Thailand. Aquat. Microb. Ecol. 22, 199-213.

Kristensen, E., Pilgaard, R., 2001. The role of fecal pellet deposition by leafeating sesarmid crabs on mineralization processes in a mangrove sediment (Phuket, Thailand). In: Aller, J.Y., Woodin, S.A., Aller, R.C. (Eds.), Organism-Sediment Interactions. Univ. South Carolina Press, Columbia, pp. 369-384.

Laegdsgaard, P., Johnson, C., 2001. Why do juvenile fish utilise mangrove habitats? J. Exp. Mar. Biol. Ecol. 257, 229-253.

Lallier-Verges, E., Perrussel, B.P., Disnar, J.-R., Baltzer, F., 1998. Relationships between environmental conditions and the diagenetic evolution of organic matter derived from higher plants in a modern mangrove swamp system (Guadeloupe, French West Indies). Org. Geochem. 29, 1663-1686.

Lee, S.Y., 1995. Mangrove outwelling - a review. Hydrobiologia 295, 203-212.

Lee, S.Y., 1997. Potential trophic importance of the faecal material of the mangrove sesarmine crab Sesarma messa. Mar. Ecol. Prog. Ser. 159, 275 284.

Lee, S.Y., 1998. Ecological role of grapsid crabs in mangrove ecosystems: a review. Mar. Freshwater Res. 49, 335-343.

Li, M.S., Lee, S.Y., 1998. Carbon dynamics of Deep Bay, eastern Pearl River Estuary, China. I. A mass balance budget and implications for shorebird conservation. Mar. Ecol. Prog. Ser. 172, 73-87.

Lin, G.H., Banks, T., Sternberg, L.D.L.O., 1991. Variation in $\delta^{13} \mathrm{C}$ values for the seagrass Thalassia testudinum and its relations to mangrove carbon. Aquat. Bot. 40, 333-341.

Marchand, C., Albéric, P., Lallier-Vergès, E., Baltzer, F., 2006. Distribution and characteristics of dissolved organic matter in mangrove sediments pore waters along the coastline of French Guiana. Biogeochemistry 81, 59-75.

Marchand, C., Baltzer, F., Lallier-Verges, E., Alberic, P., 2004. Pore-water chemistry in mangrove sediments: relationship with species composition and developmental stages (French Guiana). Mar. Geol. 208, 361-381.

Marchand, C., Lallier-Vergès, E., Baltzer, F., 2003. The composition of sedimentary organic matter in relation to the dynamic features of a mangrove-fringed coast in French Guiana. Estuar. Coast. Shelf Sci. 56, 119-130.

Marchand, C., Disnar, J.-R., Lallier-Verges, E., Lottier, N., 2005. Early diagenesis of carbohydrates and lignin in mangrove sediments subject to variable redox conditions (French Guiana). Geochim. Cosmochim. Acta 69, 131-142.

Matsui, N., 1998. Estimated stocks of organic carbon in mangrove roots and sediments in Hinchinbrook Channel, Australia. Mangroves Salt Marshes 2, 199-204.

Mazda, Y., Ikeda, Y., 2006. Behavior of the groundwater in a riverine-type mangrove forest. Wetl. Ecol. Manag. 14, 477-488.

McKee, K.L., Faulkner, P.L., 2000. Restoration of biogeochemical function in mangrove forests. Restor. Ecol. 8, 247-259.

Mead, R., Xu, Y., Chong, J., Jaffé, R., 2005. Sediment and soil organic matter source assessment as revealed by the molecular distribution and carbon composition of $n$-alkanes. Org. Geochem. 36, 363-370.

Meziane, T., Lee, S.Y., Mfilinge, P.L., Shin, P.K.S., Lam, M.H.W., Tsuchiya, M., 2007. Inter-specific and geographical variations in the fatty acid composition of mangrove leaves: implications for using fatty acids as a taxonomic tool and tracers of organic matter. Mar. Biol. 150, 11031113.

Mfilinge, P.L., Atta, N., Tsuchiya, M., 2002. Nutrient dynamics and leaf litter decomposition in a subtropical mangrove forest at Oura Bay, Okinawa, Japan. Trees 16, 172-180.

Mfilinge, P.L., Meziane, T., Bachok, Z., Tsuchiya, M., 2003. Fatty acids in decomposing mangrove leaves: microbial activity, decay and nutritional quality. Mar. Ecol. Prog. Ser. 265, 97-105.
Mfilinge, P.L., Meziane, T., Bachok, Z., Tsuchiya, M., 2005. Total lipid and fatty acid classes in decomposing mangrove leaves of Bruguiera gymnorrhiza and Kandelia candel: significance with respect to lipid input. J. Oceanogr. 61, 613-622.

Micheli, F., 1993. Feeding ecology of mangrove crabs in North Eastern Australia: mangrove litter consumption by Sesarma messa and Sesarma smithii. J. Exp. Mar. Biol. Ecol. 171, 165-186.

Middelburg, J.J., Nieuwenhuize, J., Slim, F.J., Ohowa, B., 1996. Sediment biogeochemistry in an East African mangrove forest (Gazi Bay, Kenya). Biogeochemistry 34, 133-155.

Middelburg, J.J., Nieuwenhuize, J., Lubberts, R.K., van de Plassche, O., 1997. Organic carbon isotope systematics of coastal marshes. Estuar. Coast. Shelf Sci. 45, 681-687.

Middleton, B.A., McKee, K.L., 2001. Degradation of mangrove tissues and implications for peat formation in Belizean island forests. J. Ecol. 89, 818828.

Moers, M.E.C., Baas, M., de Leeuw, J.W., Boon, J.J., Schenk, P.A., 1990. Occurrence and origin of carbohydrates in peat samples from a red mangrove environment as reflected by abundances of neutral monosaccharides. Geochim. Cosmochim. Acta 54, 2463-2472.

Nagelkerken, I., Blaber, S.J.M., Bouillon, S., Green, P., Haywood, M., Kirton, L.G., Meynecke, J.-O., Pawlik, J., Penrose, H.M., Sasekumar, A., Somerfield, P.J., 2008. The habitat function of mangroves for terrestrial and marine fauna: A review. Aquat. Bot. 89, 155-185.

Neilson, M.J., Richards, G.N., 1989. Chemical composition of degrading mangrove leaf litter and changes produced after consumption by mangrove crab Neosarmatium smithi (Crustacea: Decapoda: Sesarmidae). J. Chem. Ecol. 15, 1267-1283.

Nielsen, O.I., Kristensen, E., Macintosh, D.J., 2003. Impact of fiddler crabs (Uca spp.) on rates and pathways of benthic mineralization in deposited shrimp pond waste. J. Exp. Mar. Biol. Ecol. 289, 59-81.

Newell, S.Y., 1996. Established and potential impacts of eukaryotic mycelial decomposers in marine/terrestrial ecotones. J. Exp. Mar. Biol. Ecol. 200, 187-206.

Nordhaus, I., Wolff, M., Diele, K., 2006. Litter processing and population food intake of the mangrove crab Ucides cordatus in a high intertidal forest in northern Brazil. Estuar. Coast. Shelf Sci. 67, 239-250.

Odum, E.P., 1968. A research challenge: evaluating the productivity of coastal and estuarine water. In: Proceedings of the Second Sea Grant Conference, October. Univ. of Rhode Island, pp. 63-64.

Odum, E.P., Heald, E.J., 1975. The detritus based food web of an estuarine mangrove community. In: Cronin, L.E. (Ed.), Estuarine Research. Academic Press, New York, pp. 265-286.

Oku, H., Baba, S., Koga, H., Takara, K., Iwasaki, H., 2003. Lipid composition of mangrove and its relevance to salt tolerance. J. Plant Res. 116, 3745.

Ólafsson, E., Buchmayer, S., Skov, W.M., 2002. The east African decapod crab Neosarmatium meinerti (de Man) sweeps mangrove floors clean of leaf litter. Ambio 31, 569-573.

Opsahl, S., Benner, R., 1995. Early diagenesis of vascular plant tissues: lignin and cutin decomposition and biogeochemical implications. Geochim. Cosmochim. Acta 59, 4889-4904.

Opsahl, S., Benner, R., 1999. Characterization of carbohydrates during early diagenesis of five vascular plant tissues. Org. Geochem. 30, 83-94.

Poovachiranon, S., Tantichodok, P., 1991. The role of sesarmid crabs in the mineralization of leaf litter of Rhizophora apiculata in a mangrove, Southern Thailand. Res. Bull. Phuket Mar. Biol. Centre 56, 63-74.

Purvaja, R., Ramesh, R., 2001. Natural and anthropogenic methane emission from wetlands of south India. Environ. Manag. 27, 547-557.

Ridd, P.V., 1996. Flow through animal burrows in mangrove creeks. Estuar Coast. Shelf Sci. 43, 617-625.

Rafii, Z.A., Dodd, R.S., Fromard, F., 1996. Biogeographic variation in foliar waxes of mangrove species. Biochem. System Ecol. 24, 341-345.

Robertson, A.I., 1986. Leaf-burying crabs: their influence on energy flow and export from mixed mangrove forests (Rhizophora spp.) in northeastern Australia. J. Exp. Mar. Biol. Ecol. 102, 237-248.

Robertson, A.I., 1988. The decomposition of mangrove leaf litter in tropical Australia. J. Exp. Mar. Biol. Ecol. 116, 235-247. 
Robertson, A.I., Alongi, D.M., Boto, K.G., 1992. Food chains and carbon fluxes. In: Robertson, A.I., Alongi, D.M. (Eds.), Tropical Mangrove Ecosystems, Coastal and Estuarine Series 41. American Geophysical Union, Washington DC, USA, pp. 293-326.

Robertson, A.I., Blaber, S.J.M., 1992. Plankton, epibenthos and fish communities. In: Robertson, A.I., Alongi, D.M. (Eds.), Tropical Mangrove Ecosystems. American Geophysical Union, Washington, DC, pp. 173-224.

Rönnbäck, P., 1999. The ecological basis for economic value of seafood production supported by mangrove ecosystems. Ecol. Econ. 29, 235-252.

Rönnbäck, P., Troell, M., Zetterström, T., Babu, D.E., 2003. Mangrove dependence and socio-economic concerns in shrimp hatcheries of Andhra Pradesh, India. Environ. Conserv. 30, 344-352.

Sasekumar, A., 1974. Distribution of mangrove fauna on a Malayan mangrove shore. J. Anim. Ecol. 43, 51-64.

Sassen, R., 1977. Early diagenesis of fatty acids in mangrove peats, St Croix, U.S. Virgin Island. In: Interdisciplinary Studies of Peat and Coal Origins, Geological Society of America Microform Publication, $\mathrm{N}^{\circ} 7$.

Schories, D., Barletta-Bergan, A., Barletta, M., Krumme, U., Mehlig, U., Rademaker, V., 2003. The keystone role of leaf-removing crabs in mangrove forests of North Brazil. Wetl. Ecol. Manag. 11, 243-255.

Schrijvers, J., Camargo, M.G., Pratiwi, R., Vincx, M., 1998. The infaunal macrobenthos under East African Ceriops tagal mangroves impacted by epibenthos. J. Exp. Mar. Biol. Ecol. 222, 175-193.

Schwamborn, R., Voss, M., Ekau, W., Saint-Paul, U., 1999. Stable isotope composition of particulate organic matter and zooplankton in North-East Brazilian shelf waters. Arch. Fish. Mar. Res. 47, 201-210.

Sheaves, M., Molony, B., 2000. Short-circuit in the mangrove food chain. Mar. Ecol. Prog. Ser. 199, 97-109.

Skov, M.W., Hartnoll, R.G., 2002. Paradoxical selective feeding on a lownutrient diet: why do mangrove crabs eat leaves? Oecologia 131, 1-7.

Slim, F.J., Hemminga, M.A., Ochieng, C., Jannick, N.T., Cocheret de la Morinière, E., van der Velde, G., 1997. Leaf litter removal by the snail Terebralia palustris (Linneaus) and sesarmid crabs in an East African mangrove forest (Gazi Bay, Kenia). J. Exp. Mar Biol. Ecol. 215, 35-48.

Spitzy, A., Leenheer, J., 1991. Dissolved organic carbon in rivers. In: Degens, E.T., Kempe, S., Richey, J.E. (Eds.), Biogeochemistry of major world rivers Scope 42. Wiley, U.K., pp. 214-232.

Susilo, A., Ridd, P.V., Thomas, S., 2005. Comparison between tidally driven groundwater flow and flushing of animal burrows in tropical mangrove swamps. Wetl. Ecol. Manag. 13, 377-388.

Tam, N.F.Y., Wong, Y.S., 1993. Retention of nutrients and heavy-metals in mangrove sediments receiving waste-water of different strengths. Environ. Technol. 14, 719-729.

Tam, N.F.Y., Wong, Y.S., Lan, C.Y., Wang, L.N., 1998. Litter production and decomposition in a subtropical mangrove swamp receiving wastewater. J. Exp. Mar. Biol. Ecol. 226, 1-18.

Thongtham, N., Kristensen, E., 2005. Carbon and nitrogen balance of leafeating sesarmid crabs (Neoepisesarma versicolor) offered different food sources. Estuar. Coast. Shelf Sci. 65, 213-222.
Tremblay, L., Benner, R., 2006. Microbial contributions to N-immobilization and organic matter preservation in decaying plant detritus. Geochim. Cosmochim. Acta 70, 133-146.

Twilley, R.R., 1985. The exchange of organic carbon in basin mangrove forests in a southwestern Florida estuary. Estuar. Coast. Shelf Sci. 20, 543557.

Twilley, R.R., Ejdung, G., Romare, P., Kemp, W.M., 1986. A comparative study of decomposition, oxygen consumption and nutrient release for selected aquatic plants occurring in an estuarine environment. Oikos 47, 190-198.

Twilley, R.R., Chen, R.H., Hargis, T., 1992. Carbon sinks in mangrove forests and their implications to the carbon budget of tropical coastal ecosystems. Water Air Soil Pollut. 64, 265-288.

Twilley, R.R., Poro, M., Garcia, V.H., Rivera-Monroy, V.H., Zambrano, R., Bodero, A., 1997. Litter dynamics in riverine mangrove forests in the Guayas River Estuary. Ecuador. Oecologia 111, 109-122.

Valiela, I., Bowen, J.L., York, J.K., 2001. Mangrove forests: one of the world's threatened major tropical environments. Bioscience 51, 807-815.

Versteegh, G.J.M., Schefuß, E., Dupont, L., Marret, F., Sinninghe-Damst'e, J.S., Jansen, J.H.F., 2004. Taraxerol and Rhizophora pollen as proxies for tracking pas mangrove ecosystem. Geochim. Cosmochim. Acta 68, 411422.

Victor, S., Golbuu, Y., Wolanski, E., Richmond, R.H., 2004. Fine sediment trapping in two mangrove-fringed estuaries exposed to contrasting land-use intensity, Palau, Micronesia. Wetl. Ecol. Manag. 12, 277-283.

Wafar, S., Untawale, A.G., Wafar, M., 1997. Litter fall and energy flux in a mangrove ecosystem. Estuar. Coast. Shelf Sci. 44, 111-124.

Walters, B.B., Rönnbäck, P., Kovacs, J.M., Crona, B., Hussain, S.A., Badola, R., Primavera, J.H., Barbier, E., Dahdouh-Guebas, F., 2008. Ethnobiology, socio-economics and management of mangrove forests: A review. Aquat. Bot. 89, 220-236.

Webb, A.P., Eyre, B.D., 2004. The effect of natural populations of the burrowing and grazing soldier crab (Mictyris longicarpus) on sediment irrigation, benthic metabolism and nitrogen fluxes. J. Exp. Mar. Biol. Ecol. 309, 1-19.

Wells, F.E., 1984. Comparative distribution of macromolluscs and macrocrustaceans in a North-western Australian mangrove system. Aust. J. Mar. Freshw. Res. 35, 591-596.

Wolanski, E., 1995. Transport of sediment in mangrove swamps. Hydrobiologia 295, 31-42.

Woodroffe, C.D., 1992. Mangrove sediments and geomorphology. In: Robertson, A.I., Alongi, D.M. (Eds.), Tropical mangrove ecosystems. (Coastal and estuarine studies 41) AGU, Washington, pp. 7-41.

Wooller, M., Smallwood, B., Jacobson, M., Fogel, M., 2003. Carbon and nitrogen stable isotopic variation in Laguncularia racemosa (L.) (white mangrove) from Florida and Belize: implications for trophic level studies. Hydrobiologia 499, 13-23.

Zieman, J.C., Macko, S.A., Mills, A.L., 1984. Role of seagrasses and mangroves in estuarine foodwebs: temporal and spatial changes in stable isotope composition and amino acid content during decomposition. Bull. Mar. Sci. $35,380-392$. 